\title{
Stromal protein $\beta$ ig-h3 reprogrammes tumour microenvironment in pancreatic cancer
}

\author{
Delphine Goehrig ${ }_{1,2,3}$ Jérémy Nigri, ${ }^{4}$ Rémi Samain, ${ }^{5}$ Zhichong $\mathrm{Wu}_{1}{ }_{1}^{1,2,3}$ Paola Cappello, ${ }^{6}$ \\ Gaëlle Gabiane, ${ }^{1,2,3}$ Xinyi Zhang ${ }^{1,2,3}$ Yajie Zhao, ${ }^{1,2,3}$ In-San Kim, ${ }^{7}$ Marie Chanal, ${ }^{1,2,3}$ \\ Roberta Curto, ${ }^{6}$ Valerie Hervieu, ${ }^{8}$ Christelle de La Fouchardière, ${ }^{3}$ Francesco Novelli, ${ }^{6}$ \\ Pascale Milani ${ }_{1},{ }_{10}$ Richard Tomasini, ${ }^{4}$ Corinne Bousquet, ${ }_{1}^{5}$ Philippe Bertolino, ${ }^{1,2,3}$ \\ Ana Hennino $1,2,3$
}

Additional material is published online only. To view please visit the journal online (http://dx.doi.org/10.1136/ gutjnl-2018-317570)

For numbered affiliations see end of article.

Correspondence to Dr Ana Hennino, Cancer Research Center of Lyon, UMR INSERM 1052 Lyon France ; ana.hennino@inserm.fr

JN and RS contributed equally.

Received 11 September 2018 Revised 8 October 2018 Accepted 11 October 2018

Published Online First

10 November 2018

\section{SLinked}

- http://dx.doi.org/10.1136/ gutjnl-2018-317735

\section{Check for updates}

(C) Author(s) (or their employer(s)) 2019. Re-use permitted under CC BY-NC. No commercial re-use. See rights and permissions. Published by BMJ.

To cite: Goehrig D, Nigri J, Samain $\mathrm{R}$, et al. Gut

2019:68:693-707.

\section{ABSTRACT}

Objective Pancreatic cancer is associated with an abundant stromal reaction leading to immune escape and tumour growth. This massive stroma drives the immune escape in the tumour. We aimed to study the impact of $\beta$ ig-h3 stromal protein in the modulation of the antitumoural immune response in pancreatic cancer. Design We performed studies with p48-Cre; Kras ${ }^{\mathrm{G} 12 \mathrm{D}}$,

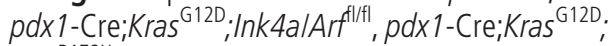
$p 53^{\mathrm{R} 172 \mathrm{H}}$ mice and tumour tissues from patients with pancreatic ductal adenocarcinoma (PDA). Some transgenic mice were given injections of anti- $\beta$ ig-h3, anti-CD8, anti-PD1 depleting antibodies. Tumour growth as well as modifications in the activation of local immune cells were analysed by flow cytometry, immunohistochemistry and immunofluorescence. Tissue stiffness was measured by atomic force microscopy. Results We identified $\beta$ ig-h3 stromal-derived protein as a key actor of the immune paracrine interaction mechanism that drives pancreatic cancer. We found that $\beta$ ig-h3 is highly produced by cancer-associated fibroblasts in the stroma of human and mouse. This protein acts directly on tumour-specific CD8 ${ }^{+} \mathrm{T}$ cells and F4/80 macrophages. Depleting $\beta$ ig-h3 in vivo reduced tumour growth by enhancing the number of activated $\mathrm{CD}^{+} \mathrm{T}$ cell within the tumour and subsequent apoptotic tumour cells. Furthermore, we found that targeting $\beta \mathrm{ig}-\mathrm{h} 3$ in established lesions released the tissue tension and functionally reprogrammed F4/80 macrophages in the tumour microenvironment.

Conclusions Our data indicate that targeting stromal extracellular matrix protein $\beta \mathrm{ig}$-h3 improves the antitumoural response and consequently reduces tumour weight. Our findings present $\beta$ ig-h3 as a novel immunological target in pancreatic cancer.

\section{INTRODUCTION}

Pancreatic ductal adenocarcinoma (PDA) is a highly aggressive cancer with a median survival of less than 6 months and a 5 -year survival rate of $3 \%-5 \%$. $^{1}$ PDA evolves through a series of pancreatic intraepithelial neoplasias (PanINs) that are accompanied by genetic modifications. Of these, the earliest and most ubiquitous is the oncogenic activation of Kras. ${ }^{2}$ In addition to the molecular and histological alterations that define cancer cells, a hallmark of PDA

\section{Significance of this study}

What is already known on this subject?

- Pancreatic cancer is a highly aggressive cancer associated with an extensive stromal reaction that blocks access of both the immune system and chemotherapies.

- Pancreatic cancer patients with high densities of $\mathrm{CD}^{+} \mathrm{T}$ cells in the juxtatumoural compartment have longer survival times.

- Cancer-associated fibroblasts within the stroma are able to attract and sequester $\mathrm{CD}^{+} \mathrm{T}$ cells in the extratumoural compartment.

What are the new findings?

- Stromal $\beta$ ig-h3 protein is highly expressed by cancer-associated fibroblasts in pancreatic cancer.

- Stromal $\beta$ ig-h3 protein acts directly on tumour-specific $\mathrm{CD}^{+} \mathrm{T}$ cells by reducing their proliferation and activation.

- Depletion of $\beta$ ig-h3 results in significantly decreased tumour growth, which was associated with increased local antitumour immunity.

How might it impact on clinical practice in the foreseeable future?

- Targeting $\beta$ ig-h3 within pancreatic tumour represents a promising therapeutic approach.

- Expression of $\beta$ ig-h3 during tumourigenesis might be used as a potential marker of early detection of pancreatic ductal adenocarcinoma.

is the prominent stromal reaction that surrounds the neoplastic cells. The cellular component of the stroma includes immune cells, such as lymphocytes, macrophages and myeloid-derived suppressor cells (MDSCs), along with vascular and neural elements (i.e. endothelial cells and neurons, respectively) as well as cancer-associated fibroblasts (CAFs).

It is now well established that activated pancreatic stellate cells (PSCs) are the major population of cells that is responsible for the production of this collagenous stroma. ${ }^{3}$ PSCs represent, at steady state, approximately $4 \%$ of the pancreas. They become activated on inflammation and are then converted 
into CAFs. Recent studies have demonstrated that CAFs are able to attract and sequester $\mathrm{CD} 8^{+} \mathrm{T}$ cells in the extratumoural compartment. This effect dampens their contact with and consequent clearing of tumour cells. ${ }^{4}$ Several studies performed in mice have shown that depleting CAFs abolishes immune suppression, ${ }^{56}$ indicating that they play an important role in modulating the local antitumoural response. In most solid tumours, as in $\mathrm{PDA}, \mathrm{CD} 8^{+} \mathrm{T}$ cell infiltration into the tumour is a factor associated with a good prognosis. ${ }^{78}$ PDA patients with high densities of $\mathrm{CD}^{+} \mathrm{T}$ cells in the juxtatumoural compartment have longer survival times than patients with lower densities. ${ }^{49}$ Therefore, restoring the antitumoural $\mathrm{CD}^{+} \mathrm{T}$ cell response might be very important in PDA.

Big-h3 (also known as TGFßi) is a $68 \mathrm{kDa}$ extracellular matrix (ECM) protein that was first isolated from A549 human lung adenocarcinoma cells that were treated with transforming growth factor beta (TGF- $\beta$ ). ${ }^{10}$ The physiological functions of $\beta$ ig-h3 have been proposed to include cell-matrix interactions and cell migration. ${ }^{11} \beta$ ig-h3 has also been shown to bind to several ECM molecules, such as collagens I, II and IV and fibronectin, proteoglycans and périostine. ${ }^{12} 13$ At the cell surface, $\beta$ ig-h3 has been shown to interact with various integrins, including $\alpha_{\mathrm{v}} \beta_{3},{ }^{14} \alpha_{1} \beta_{1}{ }^{15}$ and $\alpha_{\mathrm{y}} \beta_{5} .{ }^{16}$ We recently showed that $\beta$ ig-h3 repressed diabetogenic $\mathrm{T}$ cell activation by interfering with early factors in the TCR signalling pathway, such as Lck. ${ }^{17}$ We found that Big-h3 expression was increased in some cancers, including pancreatic cancer, ${ }^{18}$ whereas in other cancers, such as ovarian cancer and multiple myeloma, the levels of $\beta$ ig-h3 were reduced. ${ }^{19} 20$ Because the expression of $\beta$ ig-h3 was higher in pancreatic cancer, which is associated with an increase in immune suppression, we hypothesised that $\beta$ ig-h3 might play a role in directly modulating the antitumoural immune response.

To study the mechanism of $\beta$ ig-h3 modulation of the antitumoural immune response in pancreatic cancer, we took advantage of engineered mouse models of spontaneous pancreatic neoplasia and cancer that were based on Kras ${ }^{\mathrm{G} 12 \mathrm{D}}$ activation in pancreatic cells. ${ }^{2122}$ Using these models, we evaluated the effect of depleting $\beta$ ig-h3 on the modulation of antitumour immunity and its subsequent impact on tumour growth.

\section{RESULTS \\ Big-h3 is highly expressed in pancreatic neoplasias and cancers}

We previously showed that Big-h3 is expressed at low levels in the islets of Langerhans within the mouse pancreas and is not detected in acinar or duct cells within the normal mouse exocrine compartment. ${ }^{17}$ Because the expression level of $\beta$ ig-h3 was increased in PDA, ${ }^{18}$ we sought to investigate the kinetics of its protein expression during tumourigenesis. We took advantage of the $p 48$-Cre; Kras ${ }^{\mathrm{G} 12 \mathrm{D}}$ (KC) mouse model, developping PanINs in mice from 1.5 months old. ${ }^{22}$ We found that $\beta$ ig-h3 was expressed around neoplastic PanIN lesions starting at 1.5 months after birth in $\mathrm{KC}$ animals but was not expressed in the exocrine compartments of control mice (figure 1A). An analysis of the later stages of neoplastic development (ie, at 4.5 and 7 months old) revealed that $\beta$ ig-h3 expression was maintained around PanINs lesions at these ages (figure 1A). To evaluate the expression of Bigh-3 in mouse PDA, we next used $p d x 1$ Cre;Kras ${ }^{G 12 D} ;$ Ink4a/Arf ${ }^{\mathrm{fl} / \mathrm{fl}}$ (KIC) and $p d x 1$-Cre; Kras ${ }^{G 12 D} ; p 53^{R 172 H}$ (KPC) mice, which develop adenocarcinoma at 5 weeks old and 16 weeks old, respectively. ${ }^{23}$ We found that $\beta$ ig-h3 was strongly expressed in the invasive carcinoma of both the KIC and KPC animals (figure 1B). To confirm the relevance of our observations in patients with pancreatic cancer, we next analysed a cohort of 12 human PDA biopsies. Interestingly, we found that all analysed tumours strongly expressed $\beta$ ig-h3 in the extracellular compartment of the developed carcinoma (figure 1C and online supplementary figure S1). Altogether, these data suggest that Big-h3 expression is induced in the pancreas beginning in the earliest stage of PanIN onset. Our results further indicate that Big-h3 expression is maintained during the course of tumour progression in both mouse models of PDA and human pancreatic cancers.

\section{Big-h3 is produced in the stromal compartment of pancreatic neoplastic and tumour lesions}

Because $\beta$ ig-h3 was detected in pancreatic neoplastic and tumour lesions, we next investigated whether $\beta$ ig-h3 is produced by the tumour cells themselves or by the stroma-tumour microenvironment (TME). To resolve this issue, we performed coimmunofluorescence experiments using cytokeratin19 (CK19), a marker of ductal tumour cells, and PDGRF $\alpha$, which was previously shown to be a specific surface marker for CAFs. ${ }^{24}$ As shown in figure $2 \mathrm{~A}$, we found that $\beta$ ig-h3 expression was mainly localised in PDGRF $\alpha^{+}$stromal cells. PDGFR $\alpha$ also co-localised with $\alpha$ SMA, another hallmark of myofibroblastes (figure $2 \mathrm{~A}$ ). ${ }^{25}$ These observations were further confirmed in the PDA from KIC mice (figure 2B, online supplementary figure S2A,B). Interestingly, we found that $\beta$ ig-h3 expression was mutually exclusive with the expression of CK19 in all analysed PanINs, suggesting that duct cells lack $\beta$ ig-h3 expression (figure 2A,B and online supplementary figure $\mathrm{S} 2 \mathrm{~B}$ ).

Next, we used CD45, EPCAM and PDGRFo, which are cell surface markers, to sort neoplastic duct cells $\left(\mathrm{CD} 45^{-} \mathrm{EPCAM}^{+}\right)$ and CAFs $\left(\mathrm{CD}_{4} 5^{-} \mathrm{PDGRF} \alpha^{+}\right)$in samples obtained from 2.5-month-old $\mathrm{KC}$ mice pancreatic tissues (figure $2 \mathrm{C}$ and online supplementary figure S2). We used EPCAM as a marker to sort live ductal cells since they coexpressed CK19 and EPCAM (online supplementary figure S2A). Quantitative reverse transcription (RT)-PCR analysis was performed on the sorted cells, and the results confirmed that $\beta$ ig- $h 3$ was more strongly expressed in CAFs than in neoplastic ductal cells (figure 2D). To further validate this result, CAFs and ductal cells were cultured in vitro for 48 hours in the presence or absence of TGF- $\beta 1$ prior to quantification using a $\beta$ ig-h3 ELISA kit. An analysis of the cell culture supernatants confirmed that while CAFs produce $\beta$ ig-h3 ex vivo $(219 \pm 12.3 \mathrm{pg} / \mathrm{mL})$, it was barely detected in the supernatants of isolated ductal cells $(28 \pm 13.5 \mathrm{pg} / \mathrm{mL})$ (figure 2E). Interestingly, we found that stimulation with TGF- $\beta 1$ potentiated the production of $\beta$ ig-h3 by both ductal cells and CAFs, yet the quantity of $\beta$ ig-h 3 produced by TGF- $\beta 1$-stimulated ductal cells never exceeded the basal level of $\beta$ ig-h3 that was produced by CAFs (figure 2E). Taken together, these data show that $\beta$ ig-h3 is produced mainly by PDGFR $\alpha^{+}$CAFs within the stromal compartment of $\mathrm{KC}$ mice.

\section{Secreted $\beta$ ig-h3 decreases Ag-specific $\mathrm{CD} 8^{+} \mathrm{T}$ cell proliferation}

Recent studies showed that CAFs attract and sequester $\mathrm{CD} 8^{+} \mathrm{T}$ cells in the extratumoural compartment to decrease their contact with and the consequent clearance of tumour cells. ${ }^{4}$ We previously showed that $\beta$ ig-h3 inhibits the capacity of diabetogenic $\mathrm{CD}^{+}{ }^{+} \mathrm{T}$ cells to kill islet $\beta$-cells. ${ }^{17}$ Because we found that $\beta$ ig-h3 is expressed in PanINs and the PDA stromal compartment, we hypothesised that it may also impact $\mathrm{T}$ cell functions within the TME. Based on these observations, we sought to determine 
A
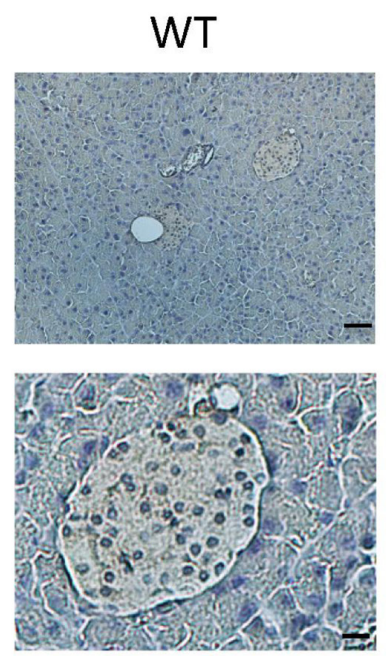

B
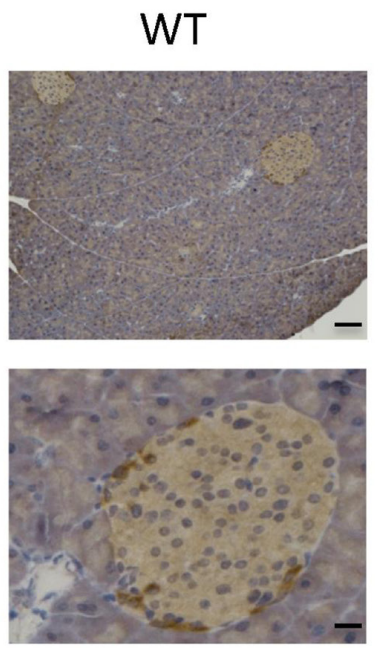

C
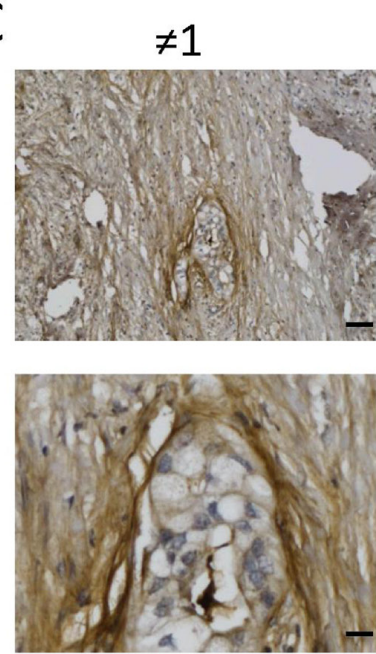

KIC
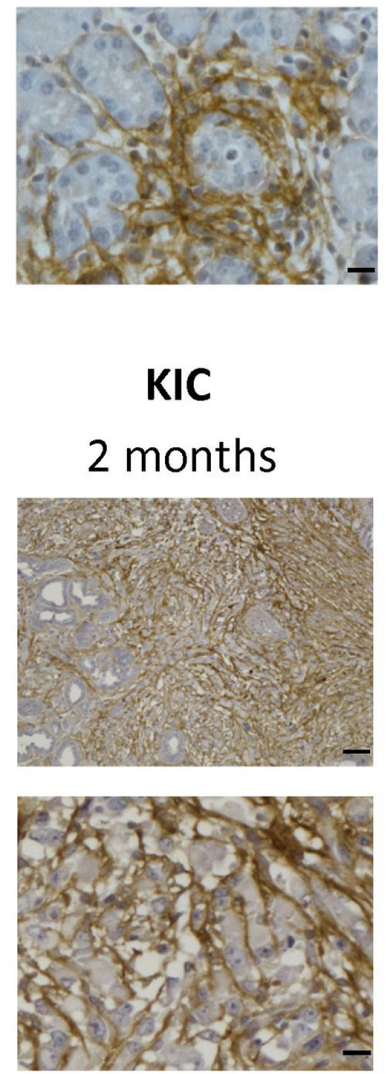

KC
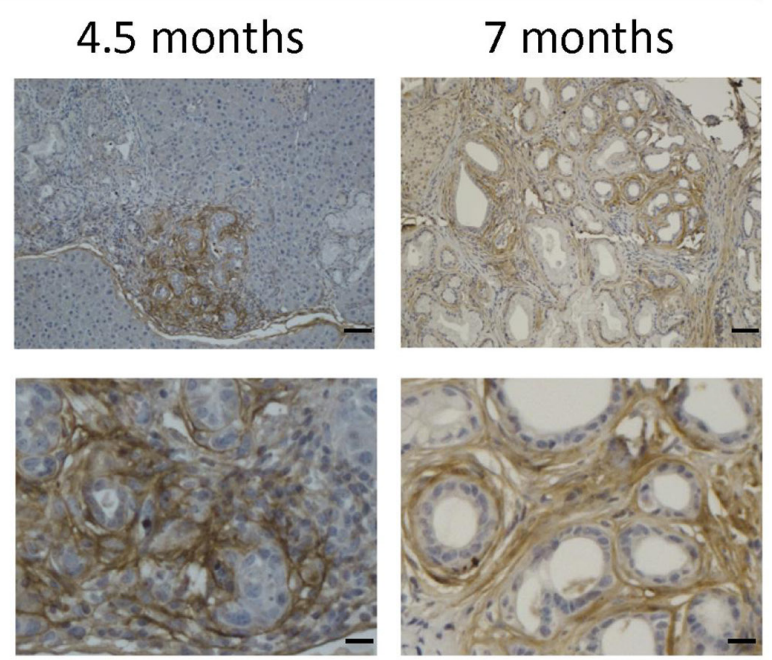

7 months

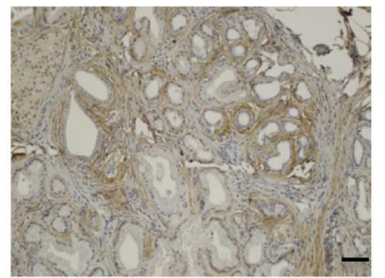

KPC
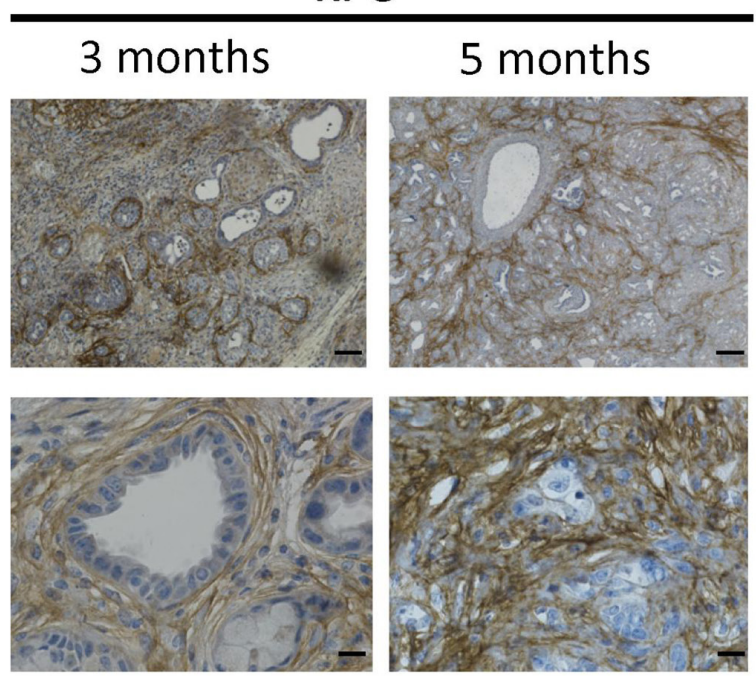

Human
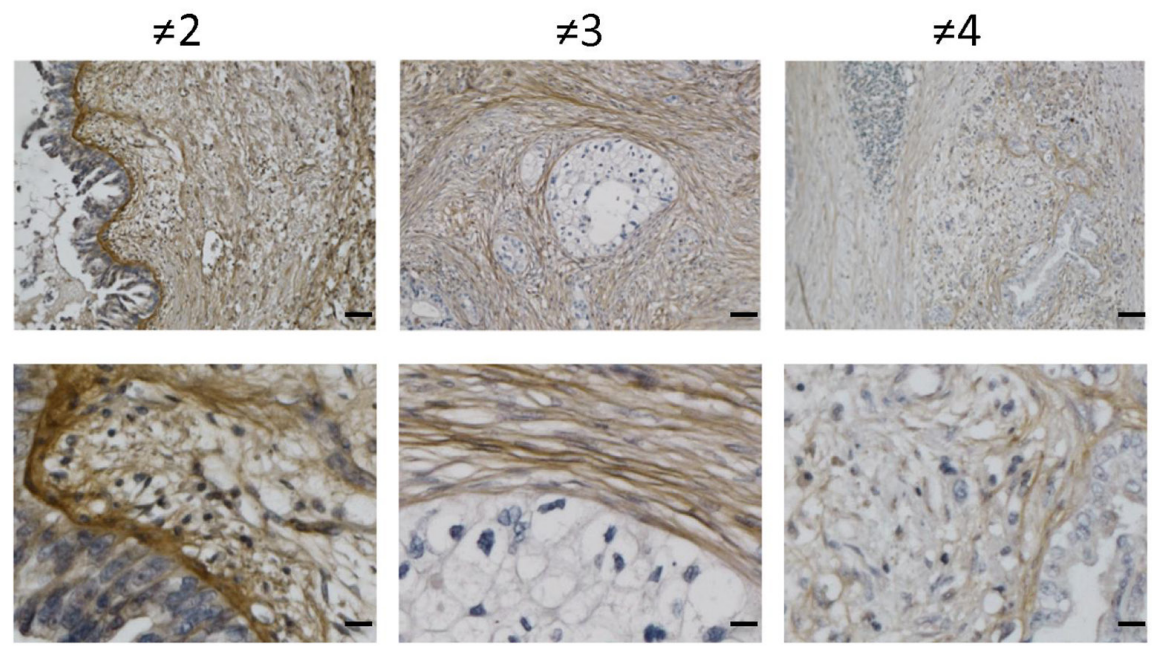

Figure 1 Big-h3 is expressed during early tumourigenesis in pancreatic cancer. Representative immunohistochemical staining for $\beta$ ig-h3 in the pancreas in KC (A) Wild type (WT) mice at 1.5 months, 4.5 months and 7 months old; (B) WT KIC mice at 2 months old and KPC mice at 3 and 5

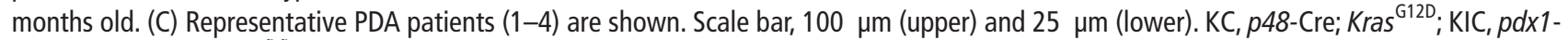

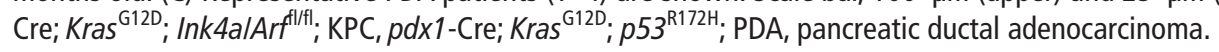



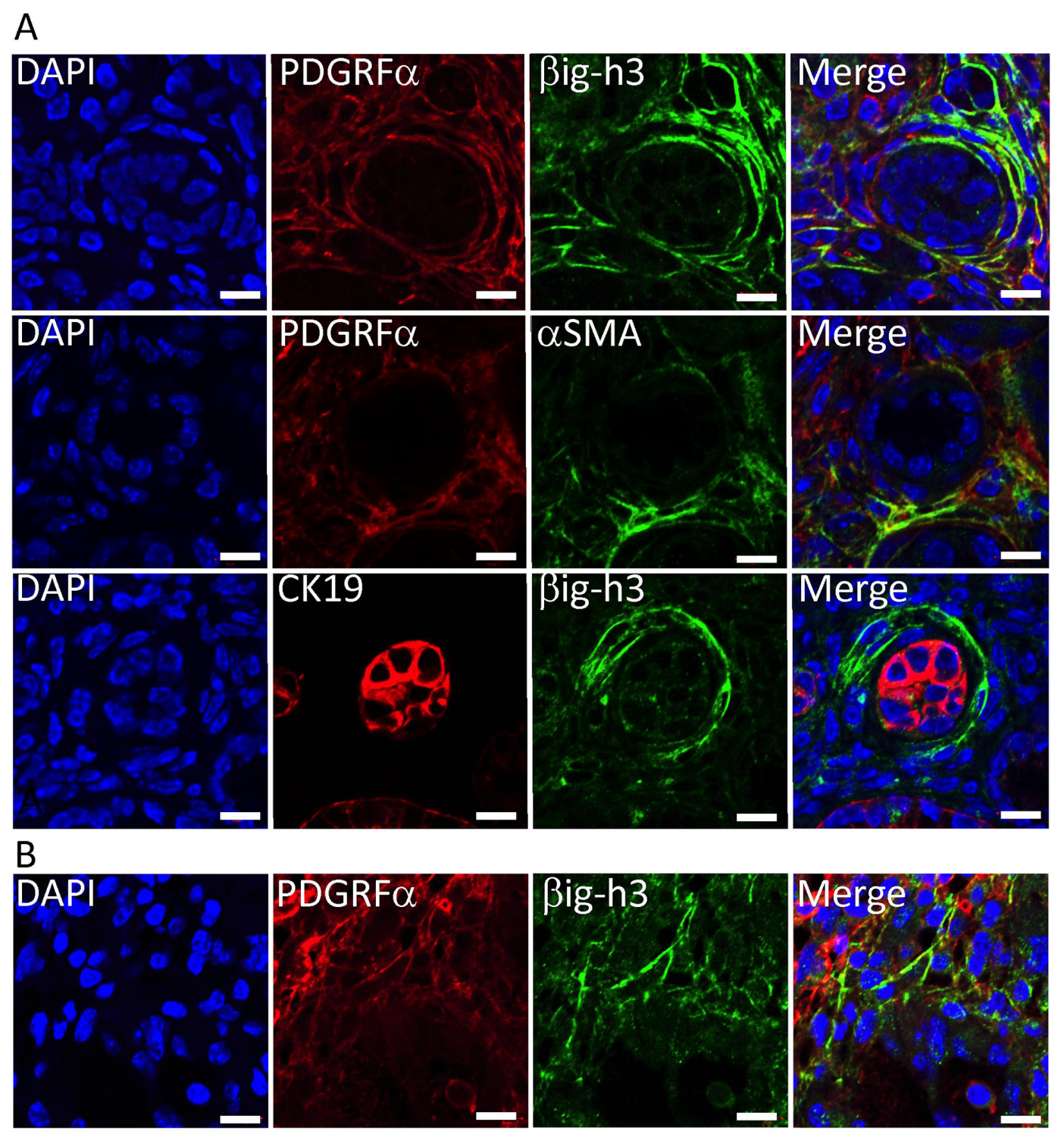

C

D

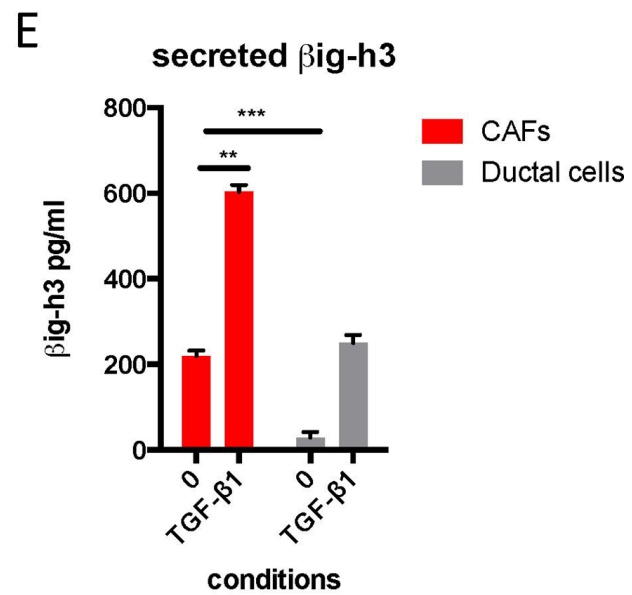

Figure 2 Big-h3 is expressed mainly in the stromal compartment. Immunofluorescence staining in a pancreas obtained from a 2.5-month-old KC mouse (A) and 2 months old KIC mouse (B) for $\beta$ ig-h3 or $\alpha$ SMA (green), PDGRF $\alpha$ or CK19 (red) and DAPI (blue). Scale bar, $10 \mu \mathrm{m}$. (C) Schematic representation of the isolated cell populations. (D) qPCR analysis of $\beta$ ig-h3 levels in freshly isolated CAF and ductal cells. TATA-binding protein (TBP) was used as a control housekeeping gene. Relative expression levels were calculated using the equation $2^{-\mathrm{CT} \text { Target }} / 2^{-\mathrm{CT} T B P}$. The results shown are representative of two independent experiments that included three mice per group. (E) CAF or ductal cells were plated in complete medium or stimulated with $20 \mathrm{ng} / \mathrm{mL}$ of TGF- $\beta 1$ for 48 hours. The levels of secreted $\beta$ ig-h3 were quantified using ELISA in the culture supernatants. The results shown are representative of two independent experiments that included three different CAF preparations and two different ductal preparations.

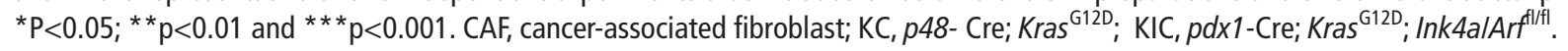


whether $\beta$ ig-h3 modulates Ag-specific responses in $\mathrm{CD} 8^{+} \mathrm{T}$ cells. We evaluated the capacity of $\beta$ ig-h3 to suppress the proliferation of ovalbumin-specific $\mathrm{CD} 8^{+} \mathrm{T}$ cells in OT1 transgenic mice that were treated with the cognate peptide Ag. We treated 5,6-carboxyfluorescein diacetate succinimidyl ester (CFSE)-labelled OT1 splenocytes with recombinant $\beta$ ig-h3 (rßig-h3) and then activated these cells with a specific ovalbumin SIINFEKL cognate peptide. We found that treatment with $\beta$ ig-h3 significantly decreased Ag-specific proliferation, which was measured as the number of divided OT1 cells that expressed the activation markers CD69 and CD44 (online supplementary figure S3A,B). Next, having shown that CAFs produce $\beta$ ig-h3 (figure 2E), we assessed the impact of the production of $\beta$ ig-h3 by CAFs on $\mathrm{T}$ cell activation. Using conditioned media, we found that CAF culture supernatants were capable of blocking proliferation in OT1 cells and that this effect was reversed by the addition of an anti- $\beta$ ig-h3-depleting-Ab (online supplementary figure S3C).

To re-stimulate $\mathrm{T}$ cells obtained from $\mathrm{KC}$ mice, we generated a KC cell line (94\% C57BL/6J background, online supplementary table 1) from pancreatic tissues obtained from 2.5 -month-old mice, as previously described. ${ }^{26}$ As expected, the cell line containing ductal and stromal components (online supplementary figure S4A) produced high levels of Big-h3 (as shown in ELISA), and this effect was strongly decreased by the addition of an anti-ßig-h3-depleting $\mathrm{Ab}$ (online supplementary figure S4B). Next, we cocultured CFSE-stained $T$ cells that were obtained from the pancreatic draining lymph nodes of $\mathrm{KC}$ mice with mitomycin-treated pancreatic KC cell line. The activation and proliferation of $\mathrm{CD} 8^{+} \mathrm{T}$ cells was subsequently evaluated in these cocultures using FACS analysis after the cells were stimulated for

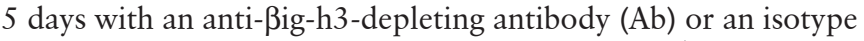
control. Using this approach, we found that $\mathrm{CD} 8^{+} \mathrm{T}$ cells that were cocultured with KC cells proliferated and expressed CD44, a marker of activation (figure 3A). More importantly, the addition of anti- $\beta$ ig-h3-depleting Abs to the cell coculture resulted in a higher rate of proliferation in $\mathrm{CD} 8^{+} \mathrm{CD} 44^{\text {high }} \mathrm{T}$ cells than that was observed in control Ab-treated cells (figure 3A). Furthermore, we found that $\mathrm{CD} 8^{+} \mathrm{T}$ cells that were stimulated by the $\mathrm{KC}$ cell line subsequently expressed increased levels of cell exhaustion markers such as programmed death receptor-1 (PD-1) and $\mathrm{T}$ cell immunoglobulin and mucin-domain containing-3 (Tim-3) compared with unstimulated condition (CD8 alone) (figure 3B,C). Adding Big-h3-depleting Abs decreased the percentage of cells expressing Tim- 3 among CD $8{ }^{+} \mathrm{CD} 44^{+} \mathrm{PD}-1^{+}$ cells in comparison with the percentage observed in the cocultures with control Ab-treated cells (figure 3C). Altogether, these results provide the first evidence indicating that $\beta$ ig-h3 modulates antigen-specific antitumoural $\mathrm{CD} 8^{+} \mathrm{T}$ cell proliferation and activation in vitro.

\section{Big-h3 interacts with CD61 on the surface of $T$ cells and F4/80 macrophages}

$\beta$ ig-h3 has been reported to induce signalling by binding to $\alpha v \beta 3$ integrins. ${ }^{27}$ We therefore evaluated the impact of $\mathrm{r} \beta$ ig-h3 on $\mathrm{CD} 8^{+} \mathrm{OT} 1$ cells and $\mathrm{T}$ cell signalling. We found that pretreatment with $\mathrm{r} \beta \mathrm{ig}$-h3 led to increased TGF $\beta 1$ 1i1 (Hic-5) stabilisation on OVA stimulation (figure 4A). Tgf $\beta 1$ il codes for Hic-5 a member of the paxilin superfamily. ${ }^{28}{ }^{29}$ We found by immunoprecipitation experiments that Hic-5 bound to Y505-Lck was enriched in the context of $\beta$ ig-h3 pretreatment (figure 4B). Furthermore, we analysed the expression of $\beta 3$ (CD61) on the surface of $\mathrm{CD}^{+}{ }^{+} \mathrm{T}$ cells. We found that the $\mathrm{CD} 8^{+} \mathrm{T}$ cells present in tumours express CD61, and we further noted that the expression of CD61 was significantly higher in tumour $\mathrm{CD} 8^{+} \mathrm{T}$ cells than in peripheral $\mathrm{CD} 8^{+} \mathrm{T}$ cells (figure $4 \mathrm{C}$ ). We next sought to determine whether $\beta$ ig-h3 signals through CD61 because treating CD ${ }^{+} \mathrm{T}$ cells with $\mathrm{r} \beta \mathrm{ig}$-h3 induced the internalisation of CD61 (figure 4C). As previously reported, ${ }^{17}$ treating $\mathrm{CD} 8^{+} \mathrm{T}$ cells with $\mathrm{r} \beta \mathrm{ig}$-h3 3 resulted in the phosphorylation of Lck at Y505, and furthermore, it colocalised with CD61 (figure 4C). These results show that $\beta$ ig-h3 interacts with CD61 at the surface of $\mathrm{CD} 8^{+} \mathrm{T}$ cells and that this interaction induces the phosphorylation of Lck at Y505 and the subsequent inhibition of this early kinase of the TCR signalling pathway. We also found that F4/80 macrophages express high levels of CD61 (not shown). We used the Raw 264.7 macrophage cell line to stimulate with Phorbol myristate acetate (PMA) or PMA $+\mathrm{r} \beta \mathrm{ig}-\mathrm{h} 3$ and assessed for Hic-5 and pErk protein expression by Western blot. We found that Hic-5 was stabilised in the presence of $\mathrm{r} \beta \mathrm{ig}$-h 3 and immunoprecipitated with Lck Y505 (figure 4D,E). More importantly, we found that macrophages cultured on collagen $+\mathrm{r} \beta$ ig-h3 layer had a diminished production of interferon gamma (IFN $\gamma$ ) and tumour necrosis factor-alpha (TNF $\alpha)$ than those cultured on collagen layer only (figure 4E,F). We confirmed our in vitro findings on FACS sorted $\mathrm{CD}^{+}{ }^{+} \mathrm{T}$ cells and F4/80 macrophages from 2.5 months KC mice pancreata, cytospined and stained for CD61, ßig-h3 and pERK. We found that CD61 colocalised with ßig-h3 and signalled through ERK in both cell types (figure 4F). These results suggest that $\beta$ ig-h3 is able to modulate both CD8 ${ }^{+}$ $T$ cell and macrophage activation in the context of the pancreatic tumour.

\section{$\mathrm{CD}^{+} \mathrm{T}$ cells are required for $\beta$ ig-h3 effect in vivo}

Because the in vitro depletion of $\beta$ ig-h3 induced the activation and proliferation of $\mathrm{CD} 8^{+} \mathrm{T}$ cells, we next sought to investigate the role of Big-h3 in modulating the host immune response during tumour growth. To explore this issue, we established an allograft system in which KC cell line (online supplementary table 1) was subcutaneously injected in C57BL/6 syngeneic mice

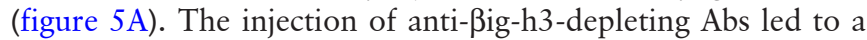
significant decrease in both the size and weight of the tumours that developed in these mice (figure $5 \mathrm{~B}, \mathrm{C}$ ). More importantly, we found that the number of $\mathrm{EPCAM}^{+} / \mathrm{CD}^{-} 5^{-}$neoplastic ductal cells was lower by FACS analysis (figure 5D). Furthermore, we found that lesions contained fewer cancer-initiating cells (defined as $\left.\mathrm{CD} 45^{-} / \mathrm{CD} 44^{+} / \mathrm{CD} 24^{+}\right)$in the mice injected with Big-h3-depleting $\mathrm{Ab}$ (figure $5 \mathrm{E}$ ). The depletion of $\beta$ ig-h3 therefore led to the accumulation of $\mathrm{CD} 8^{+} \mathrm{T}$ cells (figure $5 \mathrm{~F}$ ), although the same percentages of recruited $\mathrm{CD} 45^{+}$and $\mathrm{CD} 4^{+} \mathrm{T}$ cells were detected (figure $5 \mathrm{~F}$ and online supplementary figure $\mathrm{S} 5$ ). We also evaluated the impact of Big-h3-depleting Abs on dendritic cells, Tregs, MDSC and macrophage populations within the tumours and found that there were fewer $\mathrm{M} 2 \mathrm{CD} 206^{+}$macrophages in the mice treated with the depleting $\mathrm{Ab}$ (online supplementary figure S5). It was previously reported that both the quantity and 'quality' of tumour-infiltrating $\mathrm{CD} 8^{+} \mathrm{T}$ cells are important. ${ }^{30}$ Tumour-induced exhaustion is characterised by the expression of PD- 1 on the surface of activated $\mathrm{CD} 8{ }^{+} \mathrm{CD} 44^{+} \mathrm{T}$ cells, and the expression of this marker was significantly lower in animals treated with anti- $\beta$ ig-h3-depleting Abs than in control-treated animals (figure $5 \mathrm{~F}$ ). $\mathrm{CD}^{+} \mathrm{T}$ cells expressed more granzyme $\mathrm{B}$, IFN $\gamma$ and TNF $\alpha$ in the animals treated with anti-Big-h3-depleting Abs than control animals (figure 5F). Furthermore, in Ag-specific B16OVA system neutralisation of the $\beta$ ig-h3 protein led to increase specific OT1 producing IFN $\gamma$ (online supplementary figure S5C). Altogether, our data show that the Ag-primed 
A

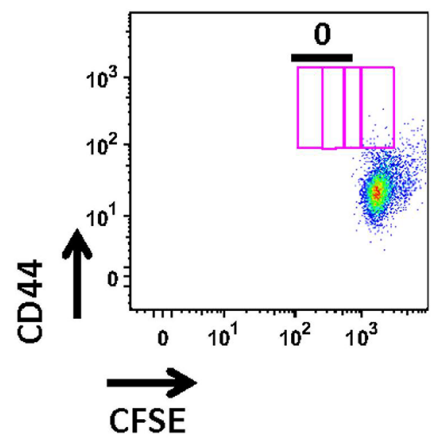

B Gated on $\mathrm{CD}^{+} \mathrm{T}$ cells

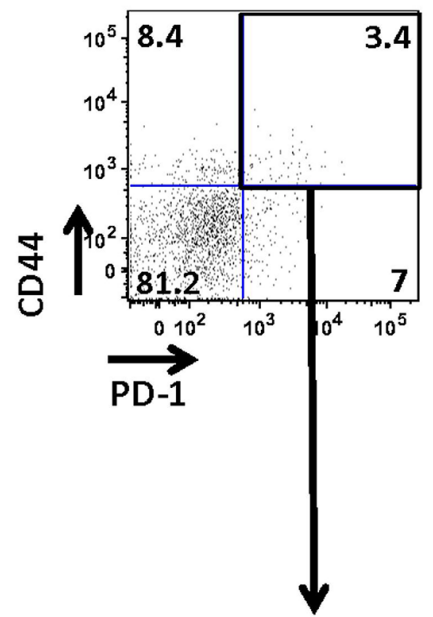

C

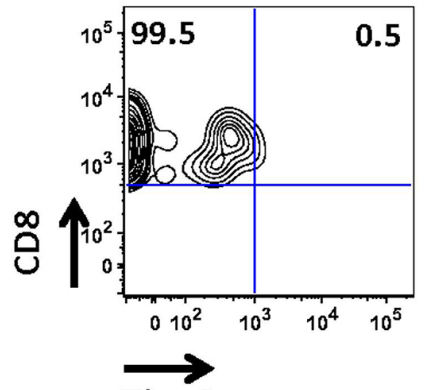

Tim-3
$\mathrm{CD} 8+\mathrm{KC}+\mathrm{ctrlAb}$
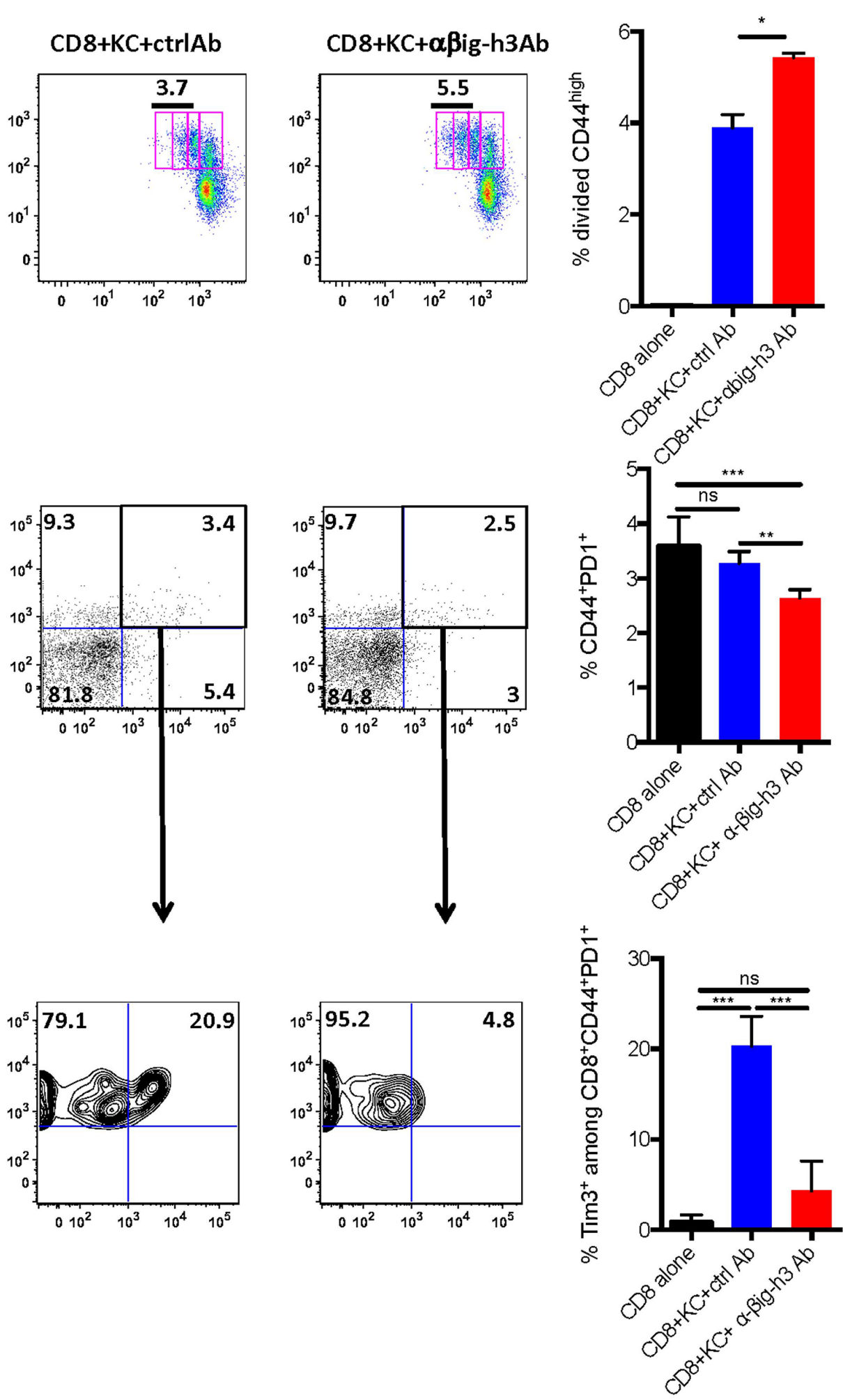

Figure 3 Secreted Big-h3 was quantified using ELISA in the culture supernatants. The results shown are representative of two independent experiments that included three different CAF preparations and two different ductal preparat. Secreted $\beta$ ig-h3 modulates specific CD8 ${ }^{+} \mathrm{T}$ cell responses. (A) Pancreatic draining lymph nodes were obtained from KC mice and cultured with mitomycin-treated KC cell line in the presence antiBig-h3 Ab or ctrl Ab for 5 days. Representative dot plots show the CFSE dilutions of CD8 ${ }^{+} T$ cells expressing CD44. The graph indicates the \% of CFSE ${ }^{\text {low }} \mathrm{CD} 8{ }^{+} \mathrm{CD} 44^{\text {high }} \mathrm{T}$ cells. Student's t-test ${ }^{*} \mathrm{p}<0.05$ (B) Representative dot plots show the expression of CD44 and PD-1 in CD8 ${ }^{+} \mathrm{T}$ cell population. The graph indicates the $\%$ of $C D 44^{+} \mathrm{PD}-1^{+}$among CD8+ T cells. ANOVA ( $\left.\mathrm{F}=13.49,{ }^{* *} \mathrm{*}<0.001\right)$ and Tukey's post hoc test. Anti- $\beta$ ig-h3-treated group compared with ctrl Ab group ( $\left.{ }^{* *} p<0.01\right)$ and to the non-stimulated group ( ${ }^{* *} p<0.01$ ) (C) Representative dot plots show the expression of Tim-3 and CD8 among CD8 ${ }^{+} \mathrm{CD} 44^{+} \mathrm{PD}-1^{+}$cells. The graph indicates the $\%$ of Tim $-3^{+}$among CD8+CD44+PD-1+T cells. ANOVA $\left(F=44.08,{ }^{* *} \mathrm{p}<0.001\right)$ and Tukey's post hoc test. Anti- $\beta$ ig-h3 treated group compared with ctrl Ab group $\left({ }^{* * *} p<0.01\right)$ and the non-stimulated group compared with ctrl Ab group $\left({ }^{* *} p<0.01\right)$. The results shown are representative of three independent experiments. Ab, antibody; ANOVA, analysis of variance; CFSE, 5,6-carboxyfluorescein diacetate succinimidyl ester; KC, p48-Cre; Kras ${ }^{\mathrm{G12D}}$; Tim-3, T cell immunoglobulin and mucin-domain containing-3. 
A

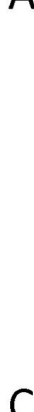

OT1

OVA

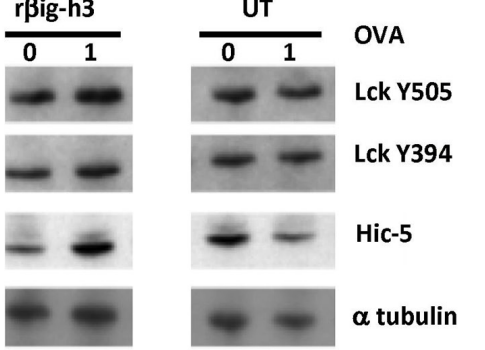

B

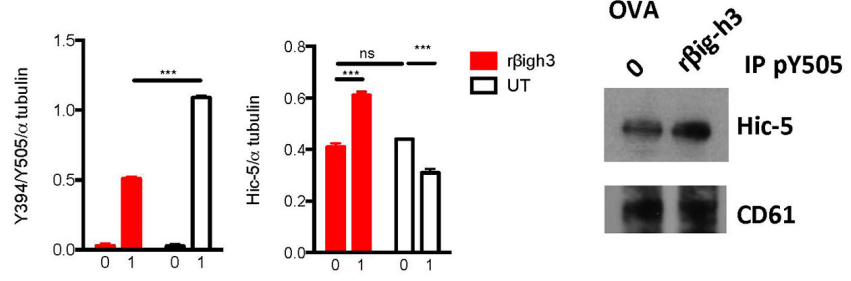

D
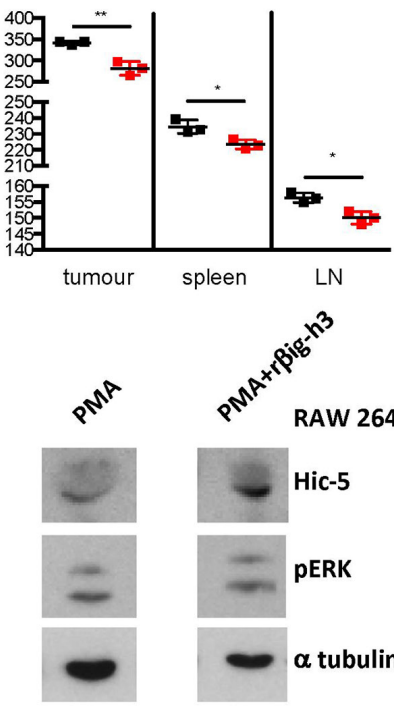

H Intra-tumoural

DAPI

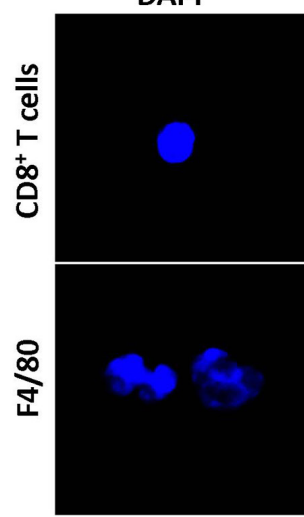

CD61

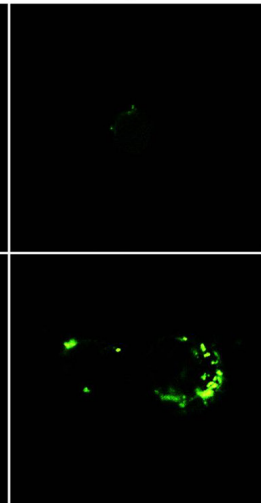

Big-h3

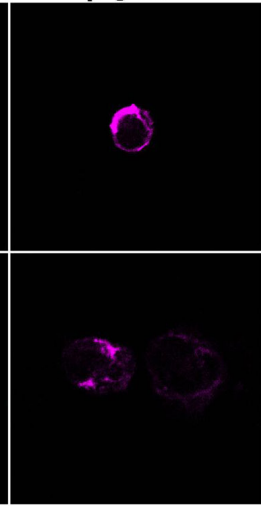

F

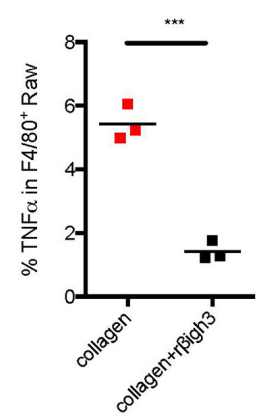

pErk

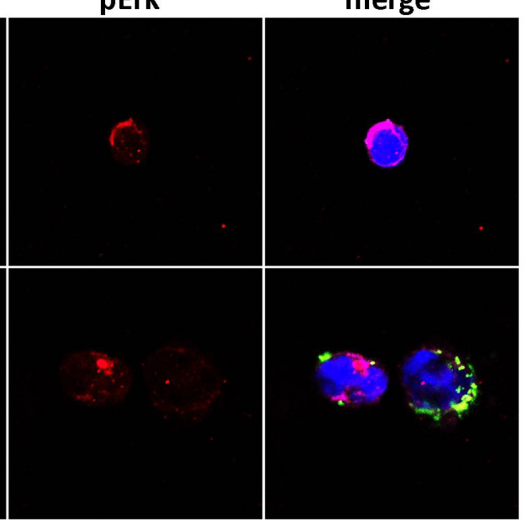

Figure 4 Big-h3 impacts both CD8 ${ }^{+} \mathrm{T}$ cells and macrophages signalling. (A) OT1 T cells were treated with $\mathrm{r} \beta i g-h 3$ for 25 min or left untreated (UT), washed and then activated with OVA peptides for $2 \min (1 \mu \mathrm{M})$. Western blot analysis for LckY505, Lck Y397, Hic-5 and $\alpha$-tubulin. Quantification

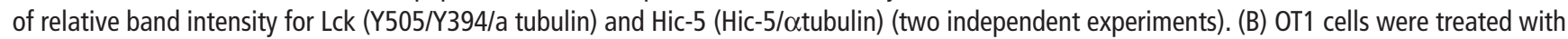
rßig-h3 for $25 \mathrm{~min}$ and then activated or not with $1 \mu \mathrm{M}$ of ovalbumine (OVA) peptide for $2 \mathrm{~min}$. The cells were subjected to IP using anti-Lck Y505 $A b$ and blotted for Hic-5 protein and CD61. (C) Mean fluorescence intensity of CD61 expression in CD8+ T cells in tumour, spleen and pancreatic lymph node (LN) at time 0 and at 24 hours after treatment with r $\beta i g-h 3$. Confocal immunofluorescence of sorted resting (0) or r $\beta i g-h 3$-treated CD8 $8^{+}$ T cells that were obtained from KC pancreata. After 24 hours, the cells were stained with DAPI or for CD61 and Lck Y505. Scale bar, $2 \mathrm{~mm}$. Confocal microscopy was used to show colocalisation between CD61 and pLck Y505. The results were calculated using Zen software according to the Manders method. At least 20 images were analysed for each molecule. (D) Raw 264.8 macrophage cell line was treated for 24 hours with PMA or PMA plus rßig-h3. Western blot analysis of Hic-5 protein et pERK1,2 and $\alpha$ tubulin. (E) Raw 264.8 cells were treated for 24 hours with PMA or PMA plus r $\beta$ ig-h3. The cells were subjected to IP using anti-Lck Y505 Ab and blotted for Hic-5 protein and CD61. Flow cytometry analysis showing percentages of intracellular IFN $\gamma(\mathrm{F})$ and TNF $\alpha(\mathrm{G})$ in Raw 264.8 macrophages after 48 hours culture on collagen or collagen+r $r i g-h 3$ layer. (H) Confocal microscopy of cytospinned intratumoural $\mathrm{CD}^{+} \mathrm{T}$ cells and $\mathrm{F} 4 / 80^{+}$macrophages from $\mathrm{KC}$ pancreata. The results shown are representative of three independent experiments. ${ }^{*} \mathrm{P}<0.05,{ }^{* *} \mathrm{p}<0.01,{ }^{* *} \mathrm{p}<0.001,{ }^{* * *} \mathrm{p}<0.0001$. Ab, antibody; KC, $p 48$-Cre; Kras ${ }^{\mathrm{G} 12 \mathrm{D}}$. 
A

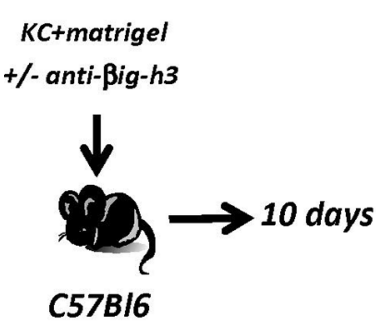

F

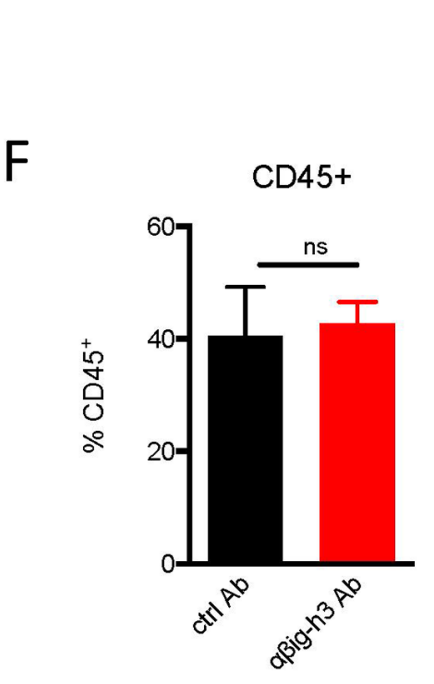

B

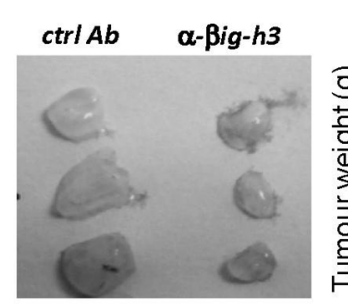

C
D

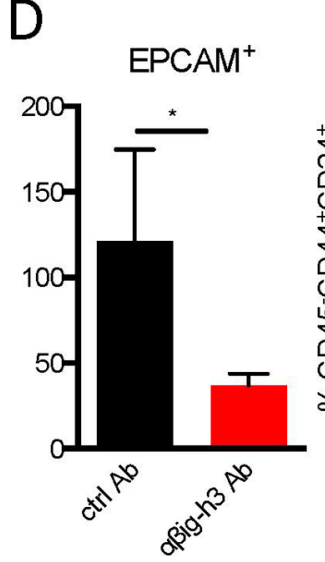

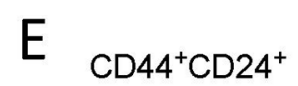
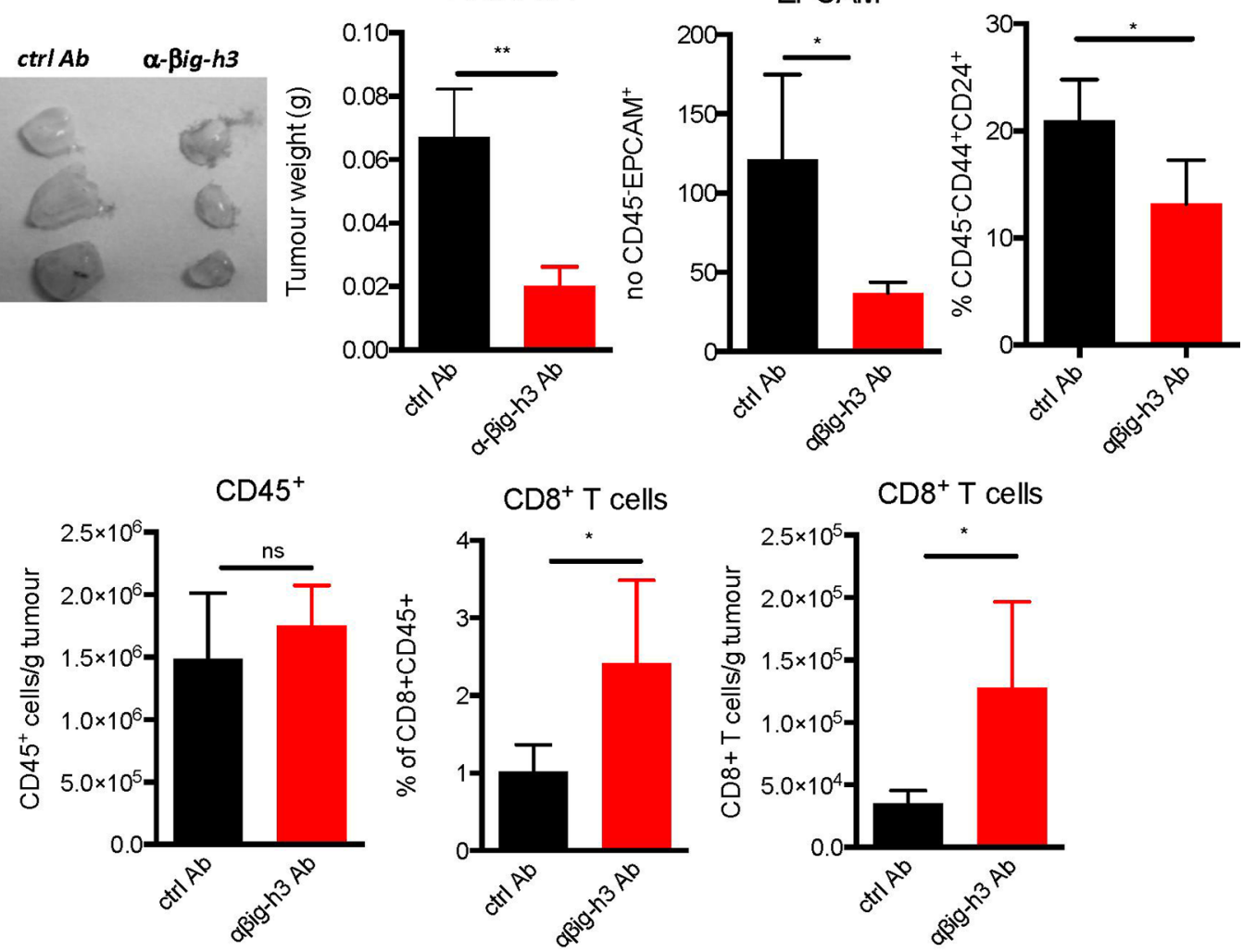

$\mathrm{PD}-1^{+} \mathrm{CD} 44^{+}$

Grz B

IFN $\gamma$

TNF $\alpha$

CD107a
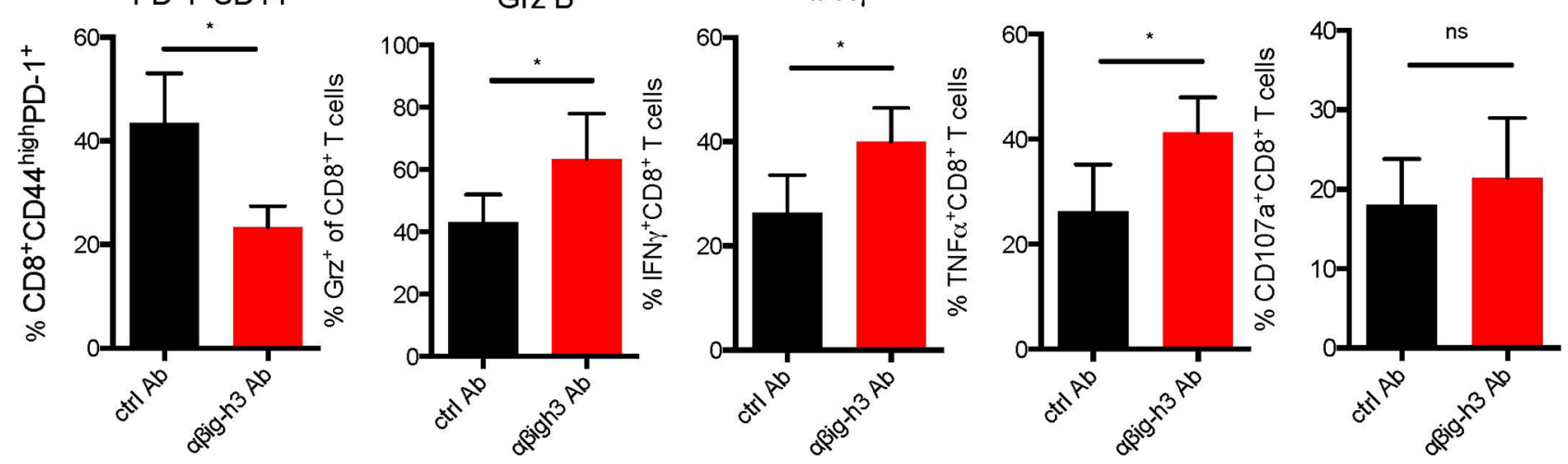

Figure $5 \quad \beta i g-h 3$ depletion increases the $C D 8^{+} T$ cell response. (A) Experimental setting. (B) Images of anti- $\beta$ ig-h3-treated and ctrl Ab-implanted tumours. (C) Tumour weights. FACS analysis of the percentages of EPCAM ${ }^{+}$CD45 $5^{-}$cells (D), CD44 ${ }^{+} C D 24^{+} C D 45^{-}$cells (E), CD45 $5^{+}$CD8 ${ }^{+}$T cells and $\mathrm{PD}-1^{+} \mathrm{CD} 44^{+}$and granzyme $\mathrm{B}+, \mathrm{IFN} \gamma+, \mathrm{TNF} \alpha+, \mathrm{CD} 107 \mathrm{a}+\mathrm{CD} 8^{+} \mathrm{T}$ cells in implanted tumours (F). The results shown are representative of three independent experiments that included five mice per group. ${ }^{*} \mathrm{P}<0.05$ and ${ }^{* *} \mathrm{p}<0.01$.

$\mathrm{CD}^{+} \mathrm{T}$ cells infiltrating tumours in the absence of the $\beta$ ig-h3 protein exhibited a less exhausted phenotype and more cytotoxic properties than in the control conditions, indicating that this protein plays a key role in the immunosuppression of the cytotoxic lymphocyte response.

To determine whether CD ${ }^{+} \mathrm{T}$ cells are required for the effect of $\beta$ ig-h3 in vivo, we subcutaneously injected KC cell line that was treated with anti- $\beta$ ig-h3-depleting or control Ab into immunodeficient Rag $2^{\mathrm{KO}}$ mice. The mice were then intravenously injected with $\mathrm{CD} 8^{+} \mathrm{T}$ cells that were isolated from the pancreatic-draining lymph nodes of $\mathrm{KC}$ mice (figure 6A). While mice injected with $\mathrm{KC}$ cells and pretreated with anti- $\beta$ ig-h3-depleting Abs displayed a similar number of recruited $\mathrm{CD} 45^{+}$cells compared with control mice (figure 6A), they exhibited a higher level of $\mathrm{CD}^{+} \mathrm{T}$ cells than that observed in the control animals (figure 6B). Moreover, concomitant with the increase in the number of $\mathrm{CD} 8^{+} \mathrm{T}$ cells, we detected a reduction in the proportion of neoplastic ductal CD $45^{-} / \mathrm{EPCAM}^{+}$cells (figure $6 \mathrm{C}$ ). These results suggest that in the absence of $\beta$ ig-h3 expression in the TME, CD ${ }^{+} \mathrm{T}$ cells accumulated within the tumour, and this phenomenon was responsible for the observed reduction in the proportion of EPCAM $^{+}$cells. One prediction based on these results would be that the observed reduction in the $\mathrm{EPCAM}^{+}$population within the tumour could be rescued by depleting $\mathrm{CD}^{+} \mathrm{T}$ cells. To test this hypothesis, we subcutaneously implanted $\mathrm{KC}$ cell line in

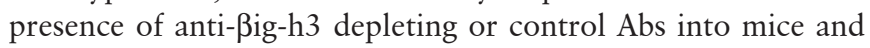




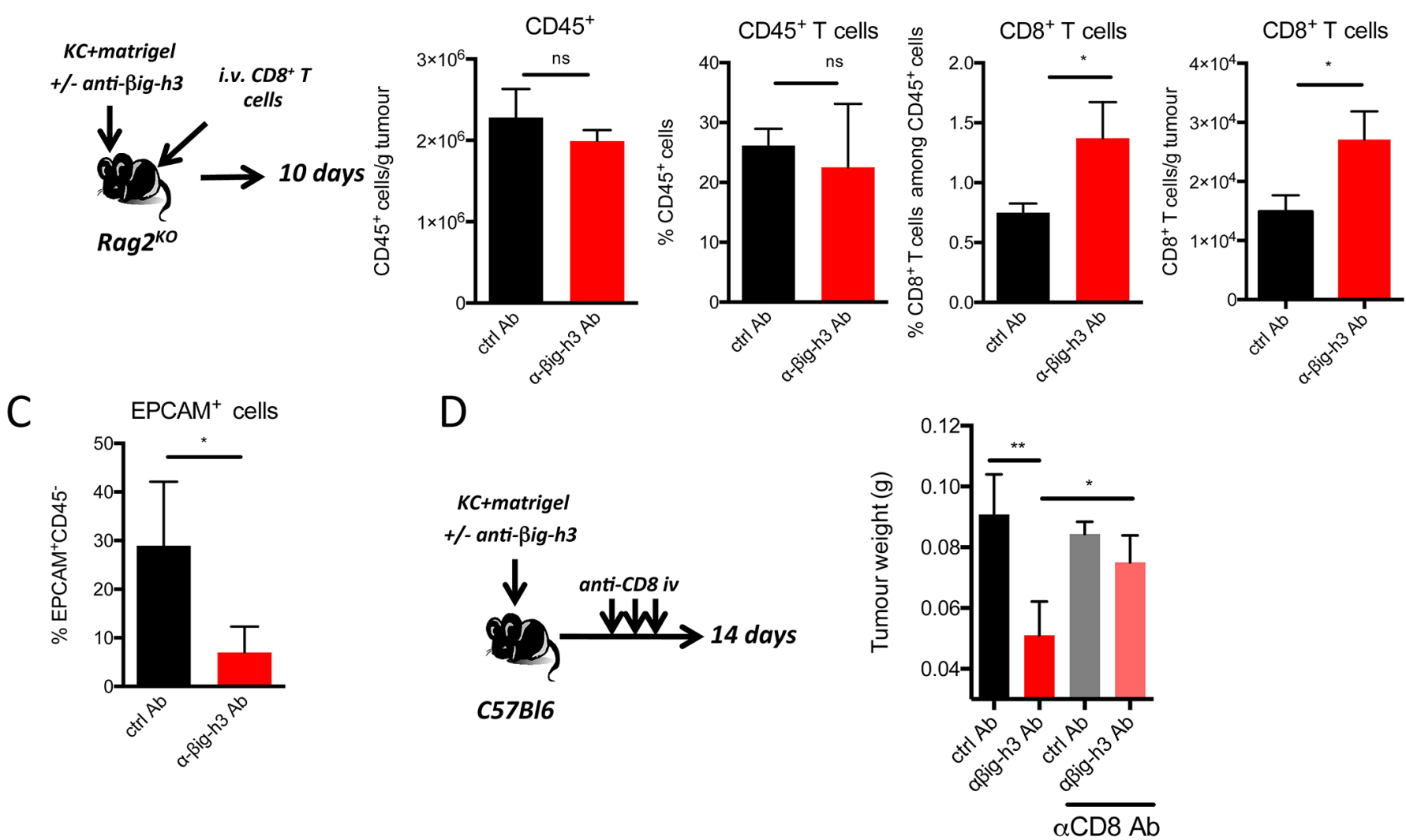

$\mathrm{E}$

KIC+matrigel

+ /- anti-ßig-h3

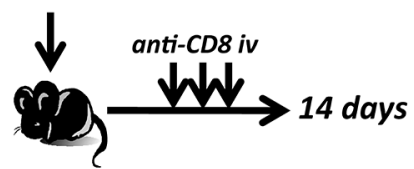

$\mathrm{F}$

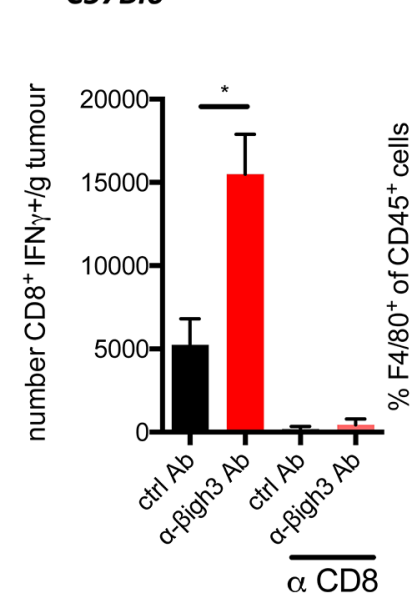

$G$

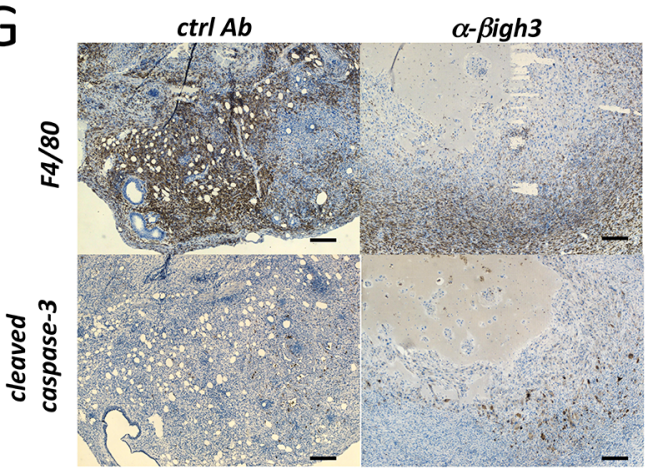

Figure 6 Big-h3 depletion affects tumour growth in both early and advanced lesions. (A) Experimental setting. (B) Percentage of $C D 45^{+}, \mathrm{CD}^{+} \mathrm{T}$ cells among $\mathrm{CD}^{+} 5^{+}$cells and numbers/g and the percentage of EPCAM ${ }^{+}$cells among $\mathrm{CD}^{-} 5^{-}$cells (C). (D) Experimental setting. Tumour weights. E) Experimental setting. (F) FACS analysis of the number of $\mathrm{CD}^{+}$IFN $\gamma+\mathrm{T}$ cells and F4/80/g of tumour. (G) Representative immunohistochemistry photos for F4/80 and cleaved caspase- 3 in anti- $\beta$ ig-h3-treated and ctrl treated KIC implanted cells in CD8 ${ }^{+} \mathrm{T}$ cell depleted C57BI/6 recipients. Scale bar $100 \mu \mathrm{m}$. The results shown are representative of three independent experiments that included five mice per group. ${ }^{*} \mathrm{P}<0.05,{ }^{* *} \mathrm{p}<0.01 . \mathrm{KC}, p 48$ Cre; $\operatorname{Kras}^{\mathrm{G}}{ }^{212}$. 
then depleted the mice of $\mathrm{CD} 8^{+} \mathrm{T}$ cells (figure 6D). These treatments resulted in the depletion of more than $90 \%$ of the CD $8^{+}$ $\mathrm{T}$ cell population without altering the numbers of $\mathrm{CD} 4^{+} \mathrm{T}$ cells or F4/80 macrophages (online supplementary figure S6C,D). Although depleting $\mathrm{CD} 8^{+} \mathrm{T}$ cells did not affect the outgrowth of the implanted tumour, it did restore the tumour weight observed in the Big-h3- depleted mice at similar level of that observed in the control animals (figure 6D). These findings suggest that $\beta$ ig-h3 drives immunosuppressive TME, which inhibits T cell-mediated immune surveillance. In order to gain insight of the mechanism in advanced lesion, we injected subcutaneously KIC cell line (generated advanced lesion cell line, online supplementary figure S4B) into C57BL/6J mice in presence of control or depleting anti- $\beta$ ig-h3 $\mathrm{Ab}$ (figure $6 \mathrm{E}-\mathrm{G}$, online supplementary figure $\mathrm{S} 6 \mathrm{E}, \mathrm{F})$ in presence or absence of $\mathrm{CD} 8^{+} \mathrm{T}$ cells $\left( \pm \mathrm{CD} 8^{+}\right.$ $\mathrm{T}$ cell-depleting $\mathrm{Ab}$ ). We found that in absence of $\mathrm{CD} 8^{+} \mathrm{T}$ cells and $\beta$ ig-h3 protein, there was an increase in F4/80 macrophages (figure 6F) and increased active caspase-3 staining (figure 6G).

\section{$\beta$ ig-h3 depletion increased immune-mediated tumour clearance in vivo}

We next evaluated the therapeutic potential of targeting $\beta$ ig-h3 in KPC and KIC mice, which are two well-established mouse models that develop aggressive PDA. ${ }^{2123}$ Whereas the KIC mice

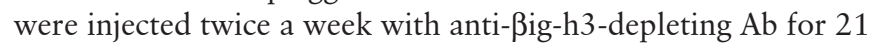
days starting when the mice were 5 weeks old (online supplementary figure $\mathrm{S} 7 \mathrm{~A}, \mathrm{~B}$ ), the KPC mice were subjected to the same when the tumourous volume was between $100 \mathrm{~mm}$ ${ }^{3}$ and $200 \mathrm{~mm}^{3}$ (figure 7A,B). Interestingly, both the KPC and KIC mice that were injected with anti- $\beta$ ig-h3-depleting Abs had significantly smaller (approximately 38\%-40\%) tumourous volumes than were observed in the untreated animals (figure 7B, online supplementary figure S7B). The quantification of the tumourous area, which was assessed using CK19 staining, revealed that there was a drastic reduction in tumourous area, from $46 \%$ to $13 \%$, in the lesions within the pancreas of the anti- $\beta$ ig-h3-depleting $\mathrm{Ab}$-treated animals than in the untreated mice (figure 7C,D). Moreover, the PanIN area was also significantly smaller in the Big-h3-depleting Ab-treated animals than in the controls (figure 7C,D). The quantification of the number of cleaved-caspase- $3^{+}$cells showed that there were significantly more apoptotic cells in the anti- $\beta$ ig-h3 Ab-treated mice than in the controls (figure 7E). More importantly, we detected an increase in the number of granzyme B-positive cells that were in close contact with cleaved-caspase- $3^{+}$cells in the anti- $\beta$ ig-h3 $\mathrm{Ab}$-treated animals (figure $7 \mathrm{~F}$ ). In order to find out if depletion of $\mathrm{CD} 8^{+} \mathrm{T}$ cells conjugated with anti- $\beta$ ig-h 3 treatment in advanced lesions restored tumour growth, we performed coinjections in $\mathrm{KPC}$ mice. We found that $\mathrm{CD} 8^{+} \mathrm{T}$ cell depletion was not able to restore tumour growth in the context of $\beta$ ig-h3 depletion (online supplementary figure $7 \mathrm{G}$ ). The tumour site displayed $\mathrm{GrzB}^{+}$positive cells to similar extent to $\beta$ ig-h3 depletion condition suggesting that other cells expressing granzyme $\mathrm{B}$, that is, F4/80 macrophages (online supplementary figure $\mathrm{S} 7 \mathrm{H}$ ) might be involved. Moreover, since it was previously reported that ßig-h3 binds to collagens, we checked by atomic force microscopy (AFM) analysis the tissue rigidity and found that overall rigidity was reduced in anti- $\beta$ ig-h3-treated mice (online supplementary figure S7D). These findings were corroborated with reduced collagen I thick fibres as determined in polarised light after Sirius Red staining, whereas the overall content of collagen was similar in untreated and Ab-treated animals (figure $7 \mathrm{G}, \mathrm{H}$ ). This stiffness release may have contributed to synergistic effect observed in the combination therapy (anti- - ig-h3 and anti-PD-1 Abs) since this treatment led to further increased GrzB positive cells (online supplementary figure S7E,F) compared with antißig-h3 depleting condition alone. Further investigations, should reveal the benefit of anti- $\beta$ ig-h3 therapy in immune-excluded PDA tumour types.

\section{DISCUSSION}

The roles host immunity plays in regulating tumourigenesis and tumour progression are critical. ${ }^{31}$ However, immune cells within the TME fail to exert an effective antitumour immune response. ${ }^{32}$ This phenomenon is largely because an effective antitumoural immune response is unable to 'reach' the tumourous zone and is maintained 'physically and functionally' restricted to the surrounding microenvironment. In the TME, the stroma acts like a physical barrier that blocks access of both the immune system and chemotherapies to the tumour. ${ }^{33}$ While depleting the stroma in mice by blocking Hedgehog signalling has been shown to exert beneficial effects, ${ }^{34}$ subsequent clinical trials that targeted stromal myofibroblasts in human PDA actually accelerated disease progression, which resulted in these clinical trials being halted. Therefore, the underlying mechanisms that allow the stroma to modulate the immune response have not been fully characterised. Here, we show that the stromal matrix protein ßig-h3 directly restrains the anti-tumour immune response by inhibiting $\mathrm{CD}^{+} \mathrm{T}$ cell immunity in PDA. This strategy of immune evasion may therefore contribute to the resistance to immunotherapy that has been observed in this cancer.

PDA progression is associated with cellular and molecular changes in both the functional and stromal compartments of the pancreas. While lineage tracing experiments have shown that most preneoplastic lesions develop from pancreatic acinar cells via a process called acinar to ductal metaplasia, ${ }^{35}$ little is known about how the stroma is modulated and what its contributions are during the early stages of pancreatic cancer. Here, we show that $\beta i g-h 3$, a protein that was initially described as a secreted extracellular matrix protein that is produced mainly by fibroblasts, keratinocytes and muscle cells, ${ }^{36}$ is a novel protein that affects the pathophysiology of PDA. Our data provide insights into the role of Big-h3 in the modulation of the cellular interactions that occur in the TME during the early stages of PDA tumour development. While Big-h3 is not expressed in the exocrine compartment of the normal murine or human pancreas, we found that its expression is substantially increased within the stroma during the early stages of PDA. Interestingly, overexpressing $\beta$ ig-h3 in mice resulted in a higher incidence of spontaneous tumours than was observed in WT mice, whereas when Big-h3 was knocked out, the resulting mice were comparable to WT controls. ${ }^{37}$ These data suggest that targeting $\beta$ ig-h3 might have no substantial side effects. We found that $\beta$ ig-h3 was increased in patients with GI cancers, including oesophageal cancer, gastric cancer, hepatocarcinoma and PDA cancer. ${ }^{37}$ In patients with oesophageal cancer, secreted $\beta$ ig-h3 was detected in the stroma using immunohistochemistry. Patients with high levels of $\beta$ ig-h 3 in the stroma but not in tumour cells had a worse prognosis than those with low levels, indicating that this marker is a crucial contributor to a non-cell autonomous mechanism. Several lines of evidence indicate that Big-h3 densely accumulates in the stroma of PDA, where it exerts an immunosuppressive effect. First, we used T cell proliferation assays (using either a recombinant molecule or secreted in CAF supernatants) and found that $\beta$ ig-h3 exerted a suppressive effect by reducing antigen-specific activation and proliferation. Here, we provide the first evidence showing that the use of a depleting 
A

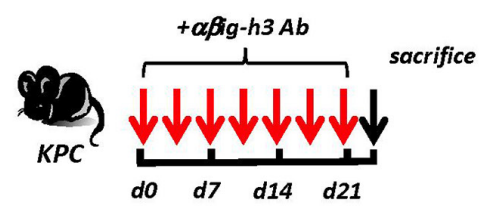

C

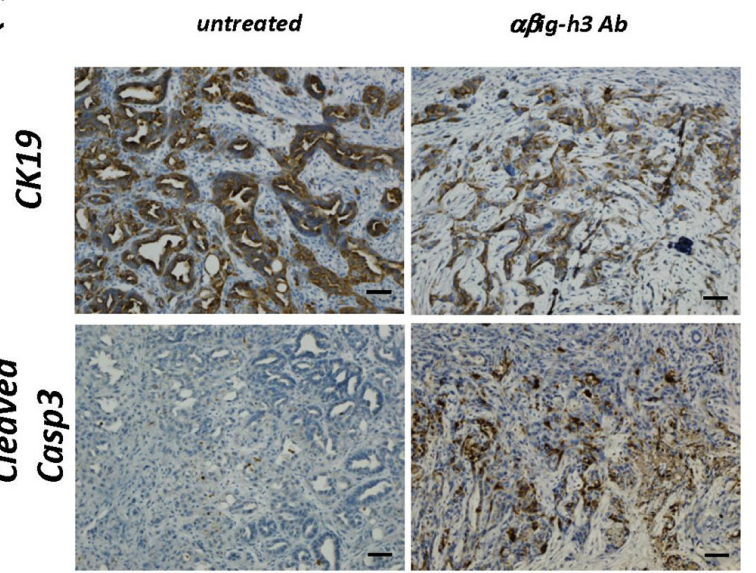

$E$

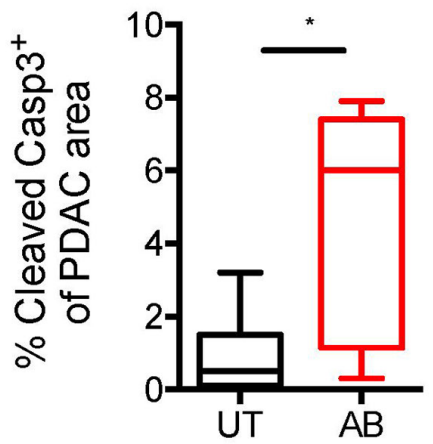

B
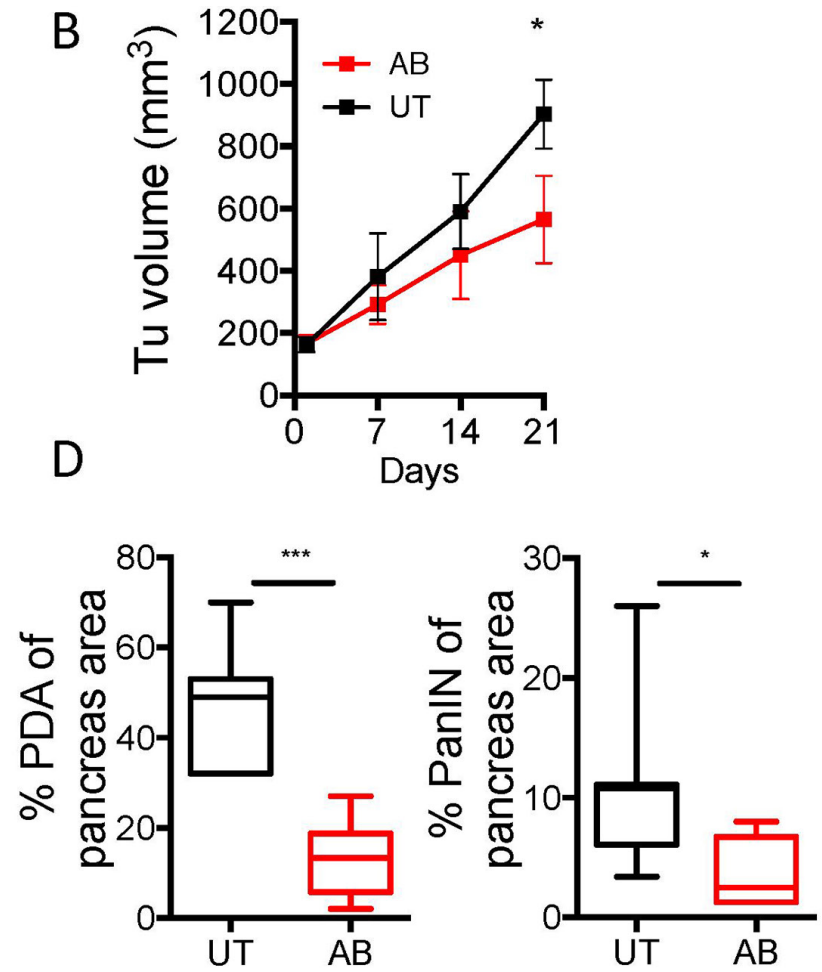

$\mathrm{F}$

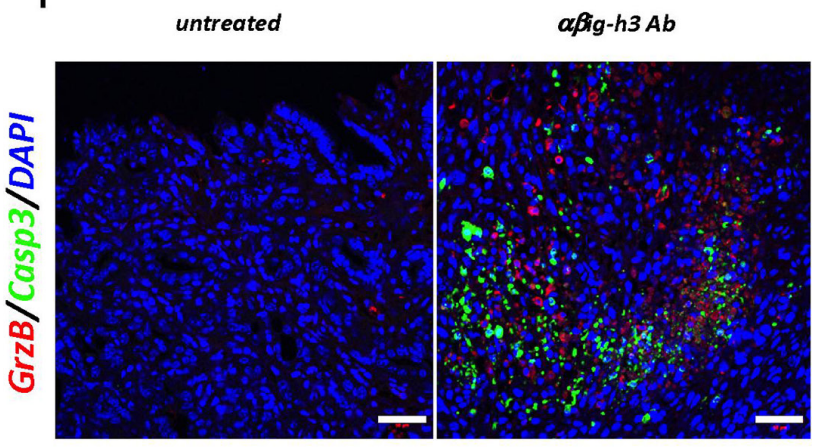

G

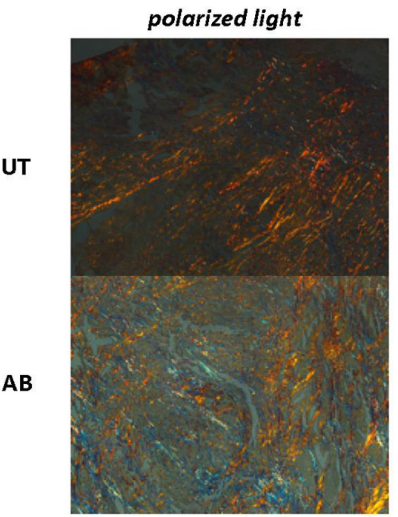

$\mathrm{H}$

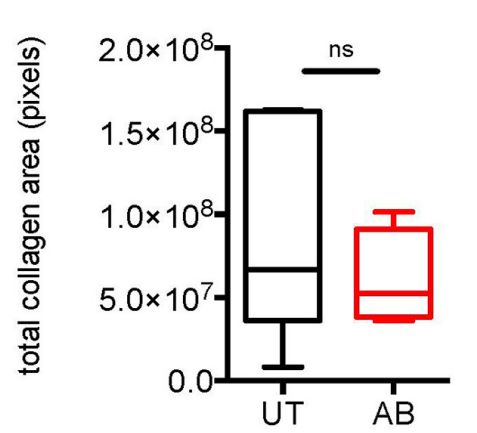

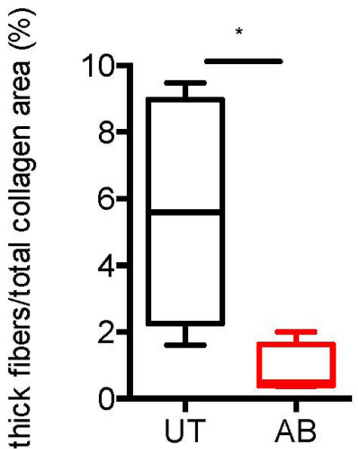

Figure 7 Big-h3 depletion in established PDA leads to reduced tumour volume. (A) Experimental protocol used for antibody depletion. (B) Tumoural volume was quantified using ultrasound (Vevo2100) in Ab-treated animals. (C) Representative immunohistochemistry for CK19 and cleaved caspase-3 in anti-ßig-h3-treated (AB) and untreated (UT) KPC mice. Scale bar, $50 \mu \mathrm{m}$. (D) Quantification of PDA and PanIN areas based on CK19 staining and (E) quantification of the results of staining for cleaved caspase-3. (F) Representative immunofluorescence staining for granzyme $B$, cleaved caspase-3 and DAPI in antißig-h3-treated and UT KPC mice. Scale bar, $50 \mu \mathrm{m}$. The experiment was performed using five to six mice per group. ${ }^{*} \mathrm{P}<0.05$ and ${ }^{* * *} p<0.001$. (H) Quantification of total collagen (transmitted light) and thick fibres (polarised light) content and representative photos in

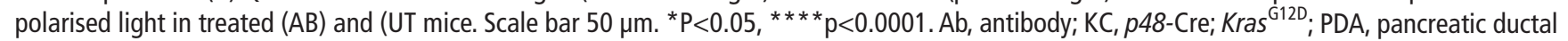
adenocarcinoma. 
$\mathrm{Ab}$ against secreted $\beta$ ig-h3 restored tumour-specific $\mathrm{CD} 8^{+} \mathrm{T}$ cell proliferation and activation and reduced cell exhaustion, which was measured using PD-1 and Tim-3 expression in vitro. Furthermore, $\beta$ ig-h3 binds to and induces signals via integrin $\beta 3$ (CD61), which was highly expressed on infiltrating CD ${ }^{+} \mathrm{T}$ cells and led to increased Hic-5 protein binding to Y505 phosphorylated Lck blunting the signal transduction. Second, the depletion of $\beta$ ig-h3 protein in vivo using an Ab strategy was accompanied by an increase in the $\mathrm{GrzB}^{+}$response. In case of rapid aggressive lesion development, the combination therapy with anti-PD-1 Ab had a synergistic effect (KIC mice). Third, the immune-mediated elimination of subcutaneously injected tumour cells was fully rescued by $\mathrm{CD} 8^{+} \mathrm{T}$ cell depletion, indicating that the $\beta \mathrm{ig}$-h3 protein plays a central role in disrupting an effective antitumoural response during the early stages of neoplasia. Considering the limitation of using 'ex vivo' generated KC line in subcutaneously injected recipients setups, we reinforced the relevance of this immune modulatory mechanism in already established PDA and found out that the TME was reprogrammed raising the exciting possibility that targeting ßig-h3 may bolster immune-mediated antitumour efficacy in patients.

What drives the production of ßig-h3 within tumours? Big-h3 was first isolated from the A549 human lung adenocarcinoma cells that were treated with TGF- $\beta .^{10}$ Its expression is regulated by TGF- $\beta$ in addition to other factors and mechanisms, including autophagy, microRNAs, interleukin (IL)-1 and IL-4. ${ }^{38}$ TGF- $\beta$ is highly expressed in several cancers, including PDA, and has been associated with tumour progression. ${ }^{39}$ In our experiments, TGF- $\beta$ increased the production of $\beta$ ig-h 3 by CAFs. The molecular mechanisms responsible for the selective increase in Big-h3 levels within the stroma but not in the ductal tumourous compartment remain to be identified.

The critical role of $\mathrm{CD} 8^{+} \mathrm{T}$ cells in tumour clearance is undisputed. $\mathrm{CD} 8^{+} \mathrm{T}$ cell tumour infiltration is thought to indicate a good prognosis. ${ }^{7}$ A previous study showed that endogenous $\mathrm{CD}^{+} \mathrm{T}$ cells are relatively sparse in PDA. ${ }^{40}$ Moreover, a recent study showed that long-term survivors PDA patients have infiltrating $\mathrm{CD} 8^{+} \mathrm{T}$ cell and neoantigens. ${ }^{8}$ In addition to the decrease in their numbers, $\mathrm{CD} 8^{+} \mathrm{T}$ cells in the TME also fail to mount an effective antitumour immune response. ${ }^{32}$ Our study reinforces the notion that $\mathrm{CD} 8^{+} \mathrm{T}$ cells are 'reprogrammed' by powerful antitumour factors. Whereas depleting $\mathrm{CD} 8^{+} \mathrm{T}$ cells did not accelerate tumour progression in the presence of $\beta$ ig-h 3 , it completely abolished the benefit conferred by $\beta$ ig-h3 neutralisation in the context of the 'early' lesions (KC model). In 'advanced' lesions (KIC and KPC model), we found that depletion of Big-h3 reprogrammes the TME in absence of $\mathrm{CD} 8^{+} \mathrm{T}$ cells. This observation supports previous studies that showed that $\alpha \beta T$ cells are entirely dispensable in PDA but can be 'reprogrammed' in efficient antitumour cells by modulating the TME by either depleting $\gamma \delta \mathrm{T}$ cells $^{41}$ or targeting focal adhesion kinase, which is an important regulator of the fibrotic and immunosuppressive microenvironment. ${ }^{42}$ We show here for the first time that the depletion of Big-h3 led to reduced tumour tension within the TME without modifying the overall content of collagen but rather the fibre thickness that has been previously shown to be associated with good prognosis in patients with PDA. ${ }^{43}$ These physical and functional modifications led to the 'reprogramming' of the TME by instructing F4/80 macrophages to secrete inflammatory and cytotoxic molecules. Furthermore, we identified Hic-5 to be associated with the phenotypical and functional changes of both $\mathrm{CD}^{+} \mathrm{T}$ cells and F4/80 macrophages. Hic-5 has been recently identified as a crucial sensor of ECM remodelling by promoting fibrillar adhesion formation. ${ }^{44}$
Another very interesting finding is that using a $\beta$ ig-h3-depleting $\mathrm{Ab}$ reduced the number of cancer-initiating cells $\left(\mathrm{CD} 45^{-} \mathrm{CD} 44^{+} \mathrm{CD} 24^{+}\right)$. Cancer-initiating cells are known to express a variety of molecules that are associated with their 'stemness' and that may potentially be recognised by the immune system as tumour antigens. ${ }^{45}$ These findings suggest that $\mathrm{CD} 8^{+}$ $\mathrm{T}$ cells play a potential role in this mechanism because the recognition of tumour Ag by $\mathrm{CD} 8^{+} \mathrm{T}$ cells initiates the elimination of those cells. Since cancer-initiating cells have been hypothesised to be responsible for metastasis in $\mathrm{PDA}^{46}$ and to be resistant to conventional chemotherapy and radiation therapy, ${ }^{47}$ the usefulness of $\beta$ ig-h3-depleting therapies might extend beyond the targeting primary tumours.

Using immunotherapy to reactivate antitumour immunity has delivered promising results in several tumour types ${ }^{48}$ but not in pancreatic cancer. Our results indicate that a promising novel opportunity to achieve this objective may be the use of depleting Abs against $\beta$ ig-h3 even in the context of immune-excluded patients with PDA. Our findings support the potential use of $\beta$ ig-h3 as a target in PDA treatments aimed at restoring beneficial antitumour immunity. As an extracellular and therefore potentially accessible and targetable protein, $\beta$ ig-h3 may indeed have high clinical value for diagnosing and treating PDA.

\section{METHODS \\ Mice}

The KC, KIC and KPC mice have been previously described. ${ }^{212349}$ OT1/Rag $2^{K O}$ transgenic mice expressing the T cell receptor were used as the source of the $\mathrm{CD} 8^{+} \mathrm{T}$ cells that were used in the in vitro experiments. ${ }^{50} \mathrm{Rag} 2{ }^{\mathrm{KO}}$ and $\mathrm{C} 57 \mathrm{BL} / 6$ mice were obtained from The Charles River Laboratories and used as the hosts in the subcutaneous tumour implantation experiments. All animal protocols were reviewed and approved in accordance with the guidelines provided by the Cancer Research Center Lyon Animal Care and Use Committee.

\section{Collection of tissue samples from mice}

Normal and tumourous pancreas were washed in phosphate buffered saline (PBS), minced into small fragments and then incubated in collagenase solution $(1 \mathrm{mg} / \mathrm{mL}$ collagenase $\mathrm{V}$ obtained from Roche in HBSS) at $37^{\circ} \mathrm{C}$ for $20 \mathrm{~min}$. The spleen and peripancreatic lymph nodes were homogenised and passed through a $70 \mu \mathrm{m}$ cell strainer to achieve single cell suspensions. Red blood cells were lysed using $\mathrm{NH}_{4} \mathrm{Cl}$ lysis buffer.

\section{Antibodies}

The following monoclonal Abs were used in flow cytometry: anti-CD45 (30-11, APC-Cy7, PE), anti-CD8 (Ly-2, V450), antiCD4 (RM4-5, V500) anti-CD44 (IM7, Alexa 700) anti-mouse OVA257-264 (SIINFEKL) peptide bound to $\mathrm{H}-2 \mathrm{~Kb}$ (PE), antiCD326 (EPCAM) (9C4; FITC), anti-CD24 (30-F1, PE-Cy7), anti-CD69 (H1.2F3, PerCP/Cy5.5), anti-CD61 (Ebioscience, 2C9.G3; FITC) anti-PDGRF $\alpha$ CD140 $\alpha$ (Abcam, 16A1; PE); anti-Ly6C PE, anti-Ly6G BV785, anti-Foxp3 Alexa 488, antiF4/80 Pe-Cy7, anti-CD206 BV650, anti-CD11b Percp Cy5, antiCD86 BV605, anti-CD80 APC-Cy7, anti-IFN $\gamma B V 650$, anti-GrzB Alexa647, anti-TNF $\alpha$ BV605, anti-NKp46 Alexa 488, antiCD107a Pe-Cy7, anti-CD29 Percp Cy5, anti-PD-1 PE, anti-Tim3 APC, anti-Lag3 Percp Cy5 and anti-CD11c Alexa 700 (all from Biolegend). The flow cytometry analyses were performed using a BD Fortessa Flow Cytometer (BD Biosciences) and analysed using either BD FACS Diva software V.5.0.1 (BD) or FlowJo (Tree Star). For the in vivo studies, the following endotoxin-free Abs 
were used: anti-CD8 (BioXcell; 2.43), anti-Bigh3 18B3, ${ }^{51}$ antiPD-1 and control polyclonal mouse Ig (BioXcell).

\section{Isolation of pancreas cell populations}

Ductal cells and CAFs were isolated using anti-CD45, anti-PDGFR $\alpha$-PE and anti-EPCAM or CD45, CD8 and F4/80 and CD3 Abs and FACS sorting.

\section{Cell lines}

The isolation and culture of KC and KIC mouse cells were performed using a protocol adapted from a previously published. ${ }^{26}$ Cells were obtained from the pancreas of 2.5 -month-old KC or KIC mice and dissociated. The cells were then plated in 6-well plates with serum-free Dulbecco's Modified Eagle Medium (DMEN). After 2 weeks, the media was changed to DMEN+10\% FCS. After thee to six passages, the cells were used in experiments. The phenotypes are described in table 1. Alternatively, mitomycin-treated KC cells were used to stimulate $\mathrm{T}$ cells that were derived from the pancreatic lymph nodes of $\mathrm{KC}$ mice. PDGFR $\alpha$-PE isolated CAF (obtained from three different $\mathrm{KC}$ mice) were cultured and amplified in vitro. CAF or ductal cells were seeded at $10^{4}$ cells/well and then stimulated using mouse TGF- $\beta 1$ at a final concentration of $20 \mathrm{ng} / \mathrm{mL}$ for 48 hours. The CAF supernatants (CAF SNs) were then collected and used in the $\mathrm{T}$ cell suppression assays.

\section{Functional T cell suppression assay}

Purified CD $8^{+} \mathrm{T}$ cells were labelled with $1 \mu \mathrm{M}$ CFSE (Invitrogen) at $37^{\circ} \mathrm{C}$ for $20 \mathrm{~min}$ in serum-free RPMI. OT1 CFSE-labelled splenocytes were stimulated with OVA (SIINFEKL) peptide for 5 days in the presence or absence of recombinant human $\beta$ ig-h3 $(\mathrm{r} \beta \mathrm{ig}-\mathrm{h} 3)$ at a final concentration of $5 \mu \mathrm{g} / \mathrm{mL}$. The antigen-specific suppression of $\mathrm{CD} 8^{+} \mathrm{T}$ cells was evaluated in coculture assays in which splenocytes obtained from OT-1 transgenic mice (antigen-specific assays) were seeded in triplicate in 96-well round bottom plates $\left(5 \times 10^{5}\right.$ cells/well). The splenocytes were cultured in the presence of CAF SN that was treated with or without anti- $\beta$ ig-h3 $\mathrm{Ab}$ and then stimulated with a cognate antigen, the OVA-derived peptide SIINFEKL $(1 \mathrm{mg} / \mathrm{mL}$; New England Peptide) for 3 days. Alternatively, mitomycin-treated KC cells were cocultured with CFSE-labelled pancreatic lymph node cells in the presence of a depleting anti- $\beta$ igh $3 \mathrm{Ab}$ or control $\mathrm{Ab}$ (BioXCell, USA) at a final concentration of $6 \mu \mathrm{g} / \mathrm{mL}$ for 5 days. Proliferation was evaluated at the end of the culture period using flow cytometry for CFSE dilution.

\section{Macrophage assay}

Raw 264.7 mouse macrophage cell line was used for phagocytosis assay. The cells were treated with PMA or PMA+r $\beta$ ig-h3 for 24 hours, and the cells were recovered and assessed for FACS staining, western blot and immunoprecipitation analysis. Alternatively, raw 264.7 cells were treated with PMA for 24 hours and seeded on collagen or on collagen $+\mathrm{r} \beta$ ig-h3 layers for 48 hours and further assessed for cytokines production by FACS staining.

\section{Short-term KC and KIC implantation studies}

KC or KIC cells $\left(5 \times 10^{5}\right)$ were subcutaneously injected with an anti- $\beta$ ig-h3 depleting $\mathrm{Ab}(6 \mu \mathrm{g})$ or isotype control $\mathrm{Ab}(6 \mu \mathrm{g}$, Bioxcell) and were embedded as plugs in a Matrigel 1:1 mix (Corning) into the flanks of normal C57BL6 or Rag $2^{K O}$ mice. The mice were then monitored for 10 or 14 days and then sacrificed at the indicated time points. The tumour grafts were then weighed, measured and processed for staining prior to flow cytometry.
$\mathrm{CD} 8^{+} \mathrm{T}$ cells were depleted in vivo by injecting the mice with two consecutive intraperitoneal injections of anti-CD8 mAbs (BioXCell, $16 \mu \mathrm{g} /$ mouse) at the indicated time points. To deplete $\beta$ ig-h3 in KC mice, the mice were intraperitoneally injected with an anti- $\beta$ ig-h3 depleting monoclonal $\mathrm{Ab}^{51}$ or a control monoclonal $\mathrm{Ab}$ (BioXCell, USA) at a concentration of $300 \mu \mathrm{g} / \mathrm{kg}$ once per week for 4 weeks. Alternatively, purified $\mathrm{CD} 8^{+}\left(10^{6}\right) \mathrm{T}$ cells were obtained from the pancreas-draining lymph nodes of $\mathrm{KC}$ mice and intravenously transferred into $\mathrm{Rag} 2^{\mathrm{KO}}$ recipients that were implanted with KC tumours. B16OVA cell line was also used in subcutaneous injection together with intravenous injection of OT1 cell in $\operatorname{Rag} 2^{K O}$ recipient mice.

\section{Treatment of KPC and KIC mice}

KPC or KIC mice were treated twice a week for a period of 21 day and the sacrificed. Tumour volume monitoring was done by VevoScan in KPC mice. $\beta$ igh 3 was used at $8 \mu \mathrm{g} /$ mouse and anti-PD-1 $20 \mu \mathrm{g} / \mathrm{mouse}$. For combo, the injections were done separately in ip at the same time (twice a week).

\section{Immunofluorescence analysis of intratumoural $\mathrm{CD}^{+} \mathrm{T}$ cells}

$\mathrm{CD} 8^{+} \mathrm{T}$ cells and $\mathrm{F} 4 / 80$ macrophages were FACS sorted (>98\%) from the pancreata of KC mice using a BD FACSAria flow cytometer. Cytospin preparations were fixed in $0.4 \%$ paraformaldehyde for $10 \mathrm{~min}$ and then permeabilised in $0.1 \%$ Triton X-100 for $10 \mathrm{~min}$. The cells were washed in PBS/0.05\% Tween and then blocked with $\mathrm{Ab}$ diluent (Dako) for 15 min before they were stained overnight at $4^{\circ} \mathrm{C}$ with $\mathrm{CD} 61$ (Ebioscience; 2C9. G3; FITC) pY505 (Cell Signaling) Abs, pERK and Big-h3 Ab. The slides were then incubated with specific anti-Fab'2-Alexa 647 and anti-Fab' -Alexa 555 (Molecular Probes) and mounted in Vectashield mounting medium with DAPI. Representative images of the pattern of localisation of each molecule are shown. All confocal analyses were repeated multiple times, and at least 20 images were analysed for each molecule. The method used to quantify the results of the colocalisation analysis was previously described. ${ }^{52}$ The data were rendered and analysed using Zen software (Zeiss).

\section{Biological resources}

Slides with pancreatic tissues obtained from patients with PDAC were collected from the La Timone and Edouard Herriot Hospitals. Paraffin-embedded pancreatic tissues (5 $\mu \mathrm{m}$ thick sections) were stained using immunohistochemistry and immunofluorescence. All experimental procedures were approved by the French National Ethics Committee.

\section{Immunohistochemistry and immunofluorescence}

Slides with $4 \mu \mathrm{m}$ thick sections of mouse or human pancreatic tissues embedded in paraffin were deparaffinised. The sections were unmasked using unmasking solution (Vector H 3300), saturated with $\mathrm{Ab}$ diluent (Dako) for $30 \mathrm{~min}$ and then incubated with primary Abs (anti-ßig-h3, Sigma; anti-caspase-3, Cell Signaling; and CK19 Troma III, DSHB) that were diluted in $\mathrm{Ab}$ diluent overnight at $4^{\circ} \mathrm{C}$. The sections were washed and then incubated with goat antirat biotinylated secondary Abs (BD Biosciences; $1: 200$ ) for 1 hour at RT. The remaining steps were performed using Vectastain ABC kits (Vector Labs). The slides were counterstained with hematoxylin. Alternatively, immunofluorescence was performed using deparaffinised and unmasked sections, which were incubated in anti- $\beta$ ig-h3, anti-PDGRF $\alpha$, anti-EPCAM, anti-GrzB and anti-Casp3 primary Abs overnight at $4^{\circ} \mathrm{C}$ and then with specific anti-Fab'2-Alexa 647 and anti-Fab 
' 2-Alexa 555 (Molecular Probes) secondary Abs. Finally, the sections were mounted in Vectashield mounting medium with DAPI.

\section{RT and $q P C R$}

RNA was extracted using a Qiagen kit from pelleted islets according to the manufacturer's instructions. RNA concentrations were measured using a Nanodrop spectrophotometer. RT was assessed using equivalent quantities of extracted RNAs (superior to $300 \mathrm{ng}$ ). cDNA was used to perform quantitative polymerase chain reaction (qPCR) analyses with Power SYBR Master Mix (Life Technologies). The following primers were used: TBP Forward 5'-TGGTGTGCACAGGAGCCAAG-3', TBP Reverse 5'-TTCACATCACAGCTCCCCAC and $\beta$ ig-h3 all-in-one qPCR (MQP028379) primers, which were obtained from GeneCopoeia.

\section{Western blot and immunoprecipitation}

For western blot analysis, $30 \mu \mathrm{g}$ of protein was loaded on the gel, then separated by $12 \%$ SDS-PAGE (Biorad) and transferred to a Hybond nitrocellulose membrane (Amersham Pharmacia Biotech). After transfer, the immunoblots were blocked by incubating with 5\% BSA in Tris-buffered saline and 0.1\% Tween 20. Next, the blots were probed overnight with the appropriate dilution of the primary Abs (anti-Lck, anti-pSrc pY416 which recognises Lck on pY394, anti-pLck pY505, anti-phospho ERK1/2 from Cell Signaling, anti-Hic-5 Ab from BD Biosciences, anti- $\alpha$ tubulin from Genetex) and revealed with either HRP-conjugated sheep antimouse or HRP-conjugated antirabbit Ab (Amersham, Pharmacia Biotech) for 1 hour at room temperature. After washing, the blots were developed using the ECL chemiluminescence method (Pierce Chemical) according to the manufacturer's protocol. For band intensity quantification, ImageLab was used. For immunoprecipitation $500 \mu \mathrm{g}$ of total protein were incubated with $1 \mu \mathrm{g}$ of anti-pLck pY505 overnight at $4^{\circ} \mathrm{C}$. pLck-associated proteins were then precipitated with protein A-Sepharose (Sigma-Aldrich) for 1 hour at $4^{\circ} \mathrm{C}$. The sepharose beads were spun down, washed, resuspended in SDS-gel sample buffer and boiled at $95^{\circ} \mathrm{C}$ for $3 \mathrm{~min}$. Immunoprecipitates were separated by $12 \%$ SDS-PAGE and immunoblotted for Hic-5.

\section{Atomic force microscopy}

We used AFM coupled with confocal microscopy to determine sequentially mechanical properties and pancreatic tissue domain identity. In AFM, the tip of a cantilever is pushed against the sample, and the deflection of this cantilever is monitored. Using the stiffness constant of the lever, the deflection indicates the resisting force of the sample. Our protocol ${ }^{53}$ allows us to measure the stiffness of sample very locally in a minimally invasive manner, by deforming the sample down to a depth of $100 \mathrm{~nm}$. In order to investigate the stiffness patterns and the different domains of the pancreatic exocrine compartment during PDA (stromal compartment and pancreatic tumour cells) at high resolution we used the quantitative nanomechanical mapping and the force volume protocols (Bruker). In these protocols, the AFM probe oscillates at low frequency while horizontally scanning the sample and a force curve in generated each time the probe made contact with the sample. The elastic modulus of sample, reflecting the stiffness, is then extracted from each curve applying the Sneddon (Hertz) model, yielding two-dimensional stiffness maps, where each pixel represents one force curve.

\section{Statistical analysis}

$P$ values were calculated using Student's t-test, (GraphPad Prism) as indicated in the figure legends. $* \mathrm{P}<0.05 ; * \mathrm{p}<0.01$;
$* * * \mathrm{P}<0.001$; and $* * * * \mathrm{p}<0.0001$. For multiple comparisons, one-way analysis of variance with Tukey's post hoc test was used.

\section{Author affiliations}

${ }^{1}$ Cancer Research Center of Lyon, UMR INSERM 1052, Lyon, France

${ }^{2}$ Université Lyon 1, Villeurbanne, France

${ }^{3}$ Centre Léon Bérard, Lyon, France

${ }^{4}$ INSERM 1068, CRCM, Marseille, France

5 UMR INSERM 1037, CRCT, Toulouse, France

${ }^{6}$ Department of Molecular Biotechnology and Health Sciences, University of Turin,

Turin, Italy

${ }^{7}$ KU-KIST School, Korea University, Seongbuk-gu, Korea

${ }^{8}$ Hospices Civils de Lyon, HEH, Lyon, France

${ }^{9}$ Ecole Normale Supérieure de Lyon, Lyon, France

${ }^{10}$ Biomeca, Lyon

Acknowledgements The authors would like to thank ANICAN (Cancer Research Center of Lyon) animal staff for maintenance of mouse strains. The authors would also like to thank Christophe Vanbelle for his helpful assistance with confocal microscopy.

Contributors DG performed the experiments and analysed the data. JN, RS, PC, $G G, X Z, Z W, Y Z, R C$ and $M C$ performed the experiments. PM performed the atomic force microscopy (AFM) experiments. VH and CDLF provided and analyed the human samples. I-SK provided the depleting $\beta$ ig-h3 antibody and designed the depletion experiments. PM performed the atomic force microscopy measurements. PB, RT, CB and FN discussed, interpreted the results and reviewed the writing of the manuscript. $\mathrm{AH}$ designed the experiments, analysed the data and wrote the manuscript. $\mathrm{AH}$ is the guarantor of this work and, as such, had full access to all data provided in the study and takes responsibility for the integrity of the data and the accuracy of the data analysis.

Funding This study was supported by grants from La Ligue Contre le Cancer (PB and $A H)$, Fondation ARC and Cancerôpole Rhône Alpes Auvergne-Oncostarter (AH), INSERM Transfert (AH), Fondation pour la recheche médicale -FDT40493 (RS). Associazione Italiana Ricerca sul Cancro (FN); University of Turin-Compagnia di San Paolo, METAIMMUNOTHER (FN) and PANTHER (PC), Italian Ministry of Health, RF2013-02354892 (FN).

Competing interests None declared.

Patient consent Not required.

Ethics approval CECCAPP Lyon.

Provenance and peer review Not commissioned; externally peer reviewed.

Open access This is an open access article distributed in accordance with the Creative Commons Attribution Non Commercial (CC BY-NC 4.0) license, which permits others to distribute, remix, adapt, build upon this work non-commercially, and license their derivative works on different terms, provided the original work is properly cited, appropriate credit is given, any changes made indicated, and the use is non-commercial. See: http://creativecommons.org/licenses/by-nc/4.0/.

\section{REFERENCES}

1 Kern SE, Shi C, Hruban RH. The complexity of pancreatic ductal cancers and multidimensional strategies for therapeutic targeting. J Pathol 2011;223:296-307.

2 Hezel AF, Kimmelman AC, Stanger BZ, et al. Genetics and biology of pancreatic ductal adenocarcinoma. Genes Dev 2006;20:1218-49.

3 Apte MV, Haber PS, Applegate TL, et al. Periacinar stellate shaped cells in rat pancreas: identification, isolation, and culture. Gut 1998;43:128-33.

4 Ene-Obong A, Clear AJ, Watt J, et al. Activated pancreatic stellate cells sequester CD8 + T cells to reduce their infiltration of the juxtatumoral compartment of pancreatic ductal adenocarcinoma. Gastroenterology 2013;145:1121-32.

5 Heinemann V, Reni M, Ychou M, et al. Tumour-stroma interactions in pancreatic ductal adenocarcinoma: rationale and current evidence for new therapeutic strategies. Cancer Treat Rev 2014;40:118-28.

6 Zhang Y, Ertl HC. Depletion of FAP + cells reduces immunosuppressive cells and improves metabolism and functions CD8+T cells within tumors. Oncotarget 2016;7:23282-99.

7 Galon J, Costes A, Sanchez-Cabo F, et al. Type, density, and location of immune cells within human colorectal tumors predict clinical outcome. Science 2006;313:1960-4.

8 Balachandran VP, Łuksza M, Zhao JN, et al. Identification of unique neoantigen qualities in long-term survivors of pancreatic cancer. Nature 2017;551:512-6.

9 De Monte L, Reni M, Tassi E, et al. Intratumor T helper type 2 cell infiltrate correlates with cancer-associated fibroblast thymic stromal lymphopoietin production and reduced survival in pancreatic cancer. J Exp Med 2011;208:469-78.

10 Skonier J, Neubauer M, Madisen L, et al. cDNA cloning and sequence analysis of beta ig-h3, a novel gene induced in a human adenocarcinoma cell line after treatment with transforming growth factor-beta. DNA Cell Biol 1992;11:511-22. 
11 Bae JS, Lee SH, Kim JE, et al. Betaig-h3 supports keratinocyte adhesion, migration, and proliferation through alpha3beta1 integrin. Biochem Biophys Res Commun 2002;294:940-8.

12 Hashimoto K, Noshiro M, Ohno S, et al. Characterization of a cartilage-derived $66-k D a$ protein (RGD-CAP/beta ig-h3) that binds to collagen. Biochim Biophys Acta 1997; 1355:303-14.

13 Billings PC, Whitbeck JC, Adams CS, et al. The transforming growth factor-betainducible matrix protein (beta)ig-h3 interacts with fibronectin. J Biol Chem 2002;277:28003-9.

$14 \mathrm{Nam} \mathrm{JO}$, Kim JE, Jeong HW, et al. Identification of the alphavbeta3 integrin-interacting motif of betaig-h3 and its anti-angiogenic effect. J Biol Chem 2003;278:25902-9.

15 Ohno S, Noshiro M, Makihira S, et al. RGD-CAP ((beta)ig-h3) enhances the spreading of chondrocytes and fibroblasts via integrin alpha(1)beta(1). Biochim Biophys Acta 1999;1451:196-205.

$16 \mathrm{Ma} \mathrm{C}$, Rong Y, Radiloff DR, et al. Extracellular matrix protein betaig-h3/TGFB promotes metastasis of colon cancer by enhancing cell extravasation. Genes Dev 2008:22:308-21.

17 Patry M, Teinturier R, Goehrig D, et al. Big-h3 Represses T-Cell Activation in Type 1 Diabetes. Diabetes 2015:64:4212-9.

18 Turtoi A, Musmeci D, Wang Y, et al. Identification of novel accessible proteins bearing diagnostic and therapeutic potential in human pancreatic ductal adenocarcinoma. J Proteome Res 2011;10:4302-13.

19 Kang S, Dong SM, Park NH. Frequent promoter hypermethylation of TGFBI in epithelial ovarian cancer. Gynecol Oncol 2010;118:58-63.

20 Kaiser MF, Johnson DC, Wu P, et al. Global methylation analysis identifies prognostically important epigenetically inactivated tumor suppressor genes in multiple myeloma. Blood 2013;122:219-26.

21 Aguirre AJ, Bardeesy N, Sinha M, et al. Activated Kras and Ink4a/Arf deficiency cooperate to produce metastatic pancreatic ductal adenocarcinoma. Genes Dev 2003;17:3112-26.

22 Hingorani SR, Petricoin EF, Maitra A, et al. Preinvasive and invasive ductal pancreatic cancer and its early detection in the mouse. Cancer Cell 2003;4:437-50.

23 Hingorani SR, Wang L, Multani AS, et al. Trp53R172H and KrasG12D cooperate to promote chromosomal instability and widely metastatic pancreatic ductal adenocarcinoma in mice. Cancer Cell 2005;7:469-83.

24 Erez N, Truitt M, Olson P, et al. Cancer-Associated Fibroblasts Are Activated in Incipient Neoplasia to Orchestrate Tumor-Promoting Inflammation in an NF-kappaB-Dependent Manner. Cancer Cell 2010;17:135-47.

25 Desmoulière A, Guyot C, Gabbiani G. The stroma reaction myofibroblast: a key player in the control of tumor cell behavior. Int J Dev Biol 2004;48:509-17.

26 Bayne LJ, Beatty GL, Jhala N, et al. Tumor-derived granulocyte-macrophage colonystimulating factor regulates myeloid inflammation and $\mathrm{T}$ cell immunity in pancreatic cancer. Cancer Cell 2012;21:822-35.

27 Tumbarello DA, Temple J, Brenton JD. B3 integrin modulates transforming growth factor beta induced (TGFBI) function and paclitaxel response in ovarian cancer cells. Mol Cancer 2012;11:36.

28 Thomas SM, Hagel M, Turner CE. Characterization of a focal adhesion protein, Hic-5, that shares extensive homology with paxillin. J Cell Sci 1999:112:181-90.

29 Brown MC, Turner CE. Paxillin: adapting to change. Physiol Rev 2004;84:1315-39.

30 Fourcade J, Sun Z, Benallaoua M, et al. Upregulation of Tim-3 and PD-1 expression is associated with tumor antigen-specific CD8+ T cell dysfunction in melanoma patients. J Exp Med 2010;207:2175-86.

31 Grivennikov SI, Greten FR, Immunity KM. inflammation, and cancer. Cell 2010;140:883-99.

32 Ruffell B, DeNardo DG, Affara NI, et al. Lymphocytes in cancer development: polarization towards pro-tumor immunity. Cytokine Growth Factor Rev 2010;21:3-10.
33 Provenzano PP, Cuevas C, Chang AE, et al. Enzymatic targeting of the stroma ablates physical barriers to treatment of pancreatic ductal adenocarcinoma. Cancer Cell 2012;21:418-29.

34 Olive KP, Jacobetz MA, Davidson CJ, et al. Inhibition of Hedgehog signaling enhances delivery of chemotherapy in a mouse model of pancreatic cancer. Science 2009;324:1457-61.

35 Strobel 0, Dor Y, Alsina J, et al. In vivo lineage tracing defines the role of acinarto-ductal transdifferentiation in inflammatory ductal metaplasia. Gastroenterology 2007;133:1999-2009.

36 LeBaron RG, Bezverkov KI, Zimber MP, et al. Beta IG-H3, a novel secretory protein inducible by transforming growth factor-beta, is present in normal skin and promotes the adhesion and spreading of dermal fibroblasts in vitro. J Invest Dermatol 1995;104:844-9.

$37 \mathrm{Han} \mathrm{B}, \mathrm{Cai} \mathrm{H}$, Chen $\mathrm{Y}$, et al. The role of TGFBI ( $\beta$ ig- $\mathrm{H} 3)$ in gastrointestinal tract tumorigenesis. Mol Cancer 2015;14:64.

38 Yokobori T, Nishiyama M. TGF- $\beta$ signaling in gastrointestinal cancers: progress in basic and clinical research. J Clin Med 2017;6:11.

39 Friess H, Yamanaka Y, Büchler M, et al. Enhanced expression of transforming growth factor beta isoforms in pancreatic cancer correlates with decreased survival. Gastroenterology 1993;105:1846-56.

40 Clark CE, Hingorani SR, Mick R, et al. Dynamics of the immune reaction to pancreatic cancer from inception to invasion. Cancer Res 2007;67:9518-27.

41 Daley D, Zambirinis CP, Seifert L, et al. gammadelta T Cells Support Pancreatic Oncogenesis by Restraining alphabeta T Cell Activation. Cell 2016;166:1485-99.

42 Jiang $\mathrm{H}$, Hegde $\mathrm{S}$, Knolhoff $\mathrm{BL}$, et al. Targeting focal adhesion kinase renders pancreatic cancers responsive to checkpoint immunotherapy. Nat Med 2016;22:851-60

43 Laklai H, Miroshnikova YA, Pickup MW, et al. Genotype tunes pancreatic ductal adenocarcinoma tissue tension to induce matricellular fibrosis and tumor progression. Nat Med 2016;22:497-505.

44 Goreczny GJ, Forsythe IJ, Turner CE. Hic- 5 regulates fibrillar adhesion formation to control tumor extracellular matrix remodeling through interaction with tensin1. Oncogene 2018;37:1699-713.

45 Parmiani G, Russo V, Marrari A, et al. Universal and stemness-related tumor antigens: potential use in cancer immunotherapy. Clin Cancer Res 2007; 13:5675-9.

46 Hermann PC, Huber SL, Herrler T, et al. Distinct populations of cancer stem cells determine tumor growth and metastatic activity in human pancreatic cancer. Cell Stem Cell 2007:1:313-23.

47 Shah AN, Summy JM, Zhang J, et al. Development and characterization of gemcitabine-resistant pancreatic tumor cells. Ann Surg Oncol 2007;14:3629-37.

48 Sharma P, Allison JP. The future of immune checkpoint therapy. Science 2015;348:56-61.

49 Ascher E, Markevich N, Schutzer RW, et al. Cerebral hyperperfusion syndrome after carotid endarterectomy: predictive factors and hemodynamic changes. J Vasc Surg 2003:37:769-77

50 Hogquist KA, Jameson SC, Heath WR, et al. T cell receptor antagonist peptides induce positive selection. Cell 1994;76:17-27.

51 Bae JS, Lee W, Son HN, et al. Anti-transforming growth factor $\beta$-induced protein antibody ameliorates vascular barrier dysfunction and improves survival in sepsis. Acta Physiol 2014;212:306-15

52 Manders EMM, Verbeek FJ, Aten JA. Measurement of co-localization of objects in dual-colour confocal images. J Microsc 1993;169:375-82.

53 Milani P, Mirabet V, Cellier C, et al. Matching Patterns of Gene Expression to Mechanical Stiffness at Cell Resolution through Quantitative Tandem Epifluorescence and Nanoindentation. Plant Physiol 2014;165:1399-408. 